Portland State University

PDXScholar

\title{
An Examination of Commercial Medicinal Plant Harvests, Mount Hood National Forest, Oregon
}

Shannon Michelle Campbell

Portland State University

Follow this and additional works at: https://pdxscholar.library.pdx.edu/open_access_etds

Part of the Nature and Society Relations Commons, and the Physical and Environmental Geography Commons

Let us know how access to this document benefits you.

\section{Recommended Citation}

Campbell, Shannon Michelle, "An Examination of Commercial Medicinal Plant Harvests, Mount Hood National Forest, Oregon" (2000). Dissertations and Theses. Paper 2245.

https://doi.org/10.15760/etd.2242

This Thesis is brought to you for free and open access. It has been accepted for inclusion in Dissertations and Theses by an authorized administrator of PDXScholar. Please contact us if we can make this document more accessible: pdxscholar@pdx.edu. 
AN EXAMINATION OF COMMERCIAL MEDICINAL PLANT HARVESTS, MOUNT HOOD NATIONAL FOREST, OREGON

by

SHANNON MICHELLE CAMPBELL

A thesis submitted in partial fulfillment of the requirements for the degree of

MASTER OF SCIENCE

in

GEOGRAPHY

Portland State University

2000 


\begin{abstract}
An abstract of the thesis of Shannon Michelle Campbell for the Master of Science in Geography presented June 6, 2000.

Title: An Examination of Commercial Medicinal Plant Harvests, Mount Hood National Forest, Oregon.
\end{abstract}

During the past fifteen years, non-timber or special forest products have become an important economic resource in the Pacific Northwest. These products are primarily derived from understory species and contribute approximately $\$ 200$ million to the regional economy. Medicinal plants are a little researched component of the non-timber forest product industry that relies on cultivated and wildcrafted (or wild-collected) medicinal plant species. This study examines the commercial extraction of wildcrafted medicinal plants from Mount Hood National Forest. Specifically, this study documents the medicinal plant species extracted from Mount Hood National Forest, their annual yield amounts, harvesting methods, and the changes in cover of target species after harvest.

This research uses survey data obtained from employees of two herbal companies and representatives of the U.S. Forest Service to describe medicinal plant extraction and administration as it pertains to the commercial extraction of plant species from Mount 
Hood National Forest. Field data were also used to examine changes in plant cover for four medicinal plant species (kinnikinnick, yarrow, Oregon grape and valerian) following harvest. Field results indicate that medicinal plant cover decreased significantly in all but one harvested sampling unit. Permanent unit markers were established at all the study sites to provide opportunities for long-term monitoring of target species responses to harvest.

Eleven medicinal plant species are commonly collected for commercial purposes from Mount Hood National Forest. The general lack of regulation and enforcement of commercial medicinal plant extraction coupled with an increasing demand for wildcrafted medicinal plants warrant a need for increased collaboration between regulatory agencies, herbal companies, and the general public. Additional management and research recommendations regarding the ecological impacts of medicinal plant removal are also presented. 


\section{THESIS APPROVAL}

The abstract and thesis of Shannon Michelle Campbell for the Master of Science in

Geography were presented June 6,2000, and accepted by the thesis committee and the Department.

COMMITTEE APPROVALS:

Keith Hadley, Chair

Barbara Brower

Martha Works

Carol Wilson

Representative of the Office of Graduate Studies

DEPARTMENT APPROVAL:

Teresa Bulman, Chair

Department of Geography 


\section{ACKNOWLEDGEMENTS}

Many thanks to Dr. Keith Hadley whose encouragement, support, advice, and fantastic editing skills have been instrumental in the progress and completion of my research. His patience and ability to work under tight time constraints are very much appreciated. Dr. Barbara Brower's support, and constructive advice are also much appreciated along with the many dinner invites. I thank the other members of my committee, Dr. Martha Works and Dr. Carol Wilson, who reviewed and commented on my thesis. I would especially like to thank Randal Buresh, the owner of Oregon's Wild Harvest for allowing me to stop in unannounced, accompany his harvesters to the field, and pick his brain for information. I appreciate the work of various field assistants, namely Boyd Bouwes, Caitlin Campbell, David Heslam, and Saraah Campbell. My parents have been especially supportive and I hope that now that my thesis is in writing, they'll have a clue about what I've been working on for the past year and a half. Thanks Boyd for the many hours invested in discussing my research, and providing the best companionship one could ask for in the field and during the writing of my thesis the past few months. 


\section{TABLE OF CONTENTS}

ACKNOWLEDGMENTS

LIST OF TABLES .. V

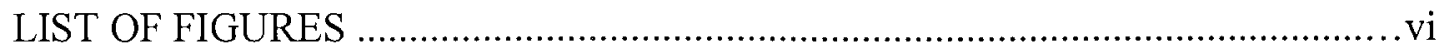

CHAPTER

I INTRODUCTION .1

Research Objective

The Pacific Northwest Special Forest Products Industry .4

The Medicinal Plant Industry .................................. 6

Medicinal Plant Conservation ....................................9

Medicinal Plants of the Mount Hood National Forest 10

Thesis Outline

II STUDY AREA 13

Climate and Vegetation .13

Geologic History .....................................................

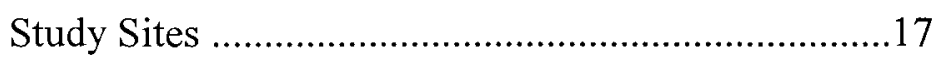

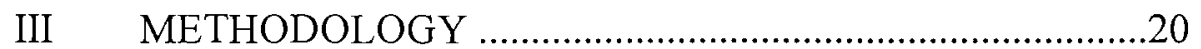

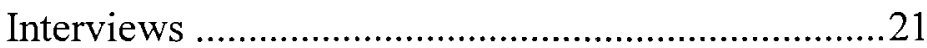

Forest Service Personnel 
Herbal Producers/Harvesters

Field Methods

$$
\begin{aligned}
& \text { Arctostaphylos uva-ursi (Kinnikinnick) } \\
& \text { Achillea millefolium (Yarrow) } \\
& \text { Valeriana sitchensis (Valerian) } \\
& \text { Berberis aquifolium (Oregon Grape) }
\end{aligned}
$$

Statistical Analysis .29

IV RESULTS

Interviews

Producers/Harvesters

Survey Results

Forest Service Employees

Statistical Results 39

Kinnikinnick

Yarrow

Oregon grape

V DISCUSSION 46

Medicinal Plant Administration 46

Medicinal Plant Monitoring- Mount Hood National Forest 48

Ecological Impacts of Medicinal Plant Harvests .......50

The Role of Disturbance in Medicinal Plant Regeneration .55

Sustainable Harvesting Guidelines and Policy..... 56

Recommendations 58

VI CONCLUSION 
REFERENCES

.66

APPENDICES

A Interview Questions for Forest Service Special Forest

Products Coordinators

B Interview Questions for Herbal Producers and Harvesters ....75 


\section{LIST OF TABLES}

TABLE

PAGE

I Medicinal Plants Extracted from the Mount Hood National Forest 33

II Pounds of Valerian Harvested from the Barlow Ranger District from 1990-1998.. .37

III Valerian Cover Estimates for the Grasshopper and Bulo Point Sites 38

IV Descriptive Statistics for Kinnikinnick Sample Plots 40

V Analysis of Variance Results for Kinnikinnick .40

VI Results for the Kinnikinnick Post-Hoc Tests ....................................41

VII Kinnikinnick Cover Class Frequencies and Chi-Square Test 42

VIII Descriptive Statistics and Mann-Whitney U-Test Results for the Flag Point and Denest Spring Sample Yarrow Sites

IX Yarrow Cover Class Frequencies and Chi-Square Tests

X Descriptive Statistics and Mann-Whitney U-Test Results for the Oregon Grape Harvest and Control Sites .45

XI Oregon Grape Cover Class Frequencies and Chi-Square Test 45 


\section{LIST OF FIGURES}

FIGURE

PAGE

1. Study Sites on Mount Hood National Forest, Oregon .......................14

2. Estimated Cover for Harvested and Control Plots ..............................39 


\section{INTRODUCTION}

Forests of the Pacific Northwest have been a valuable source of timber for over a century. Recently, however, increased cutting restrictions and shifts in timber management practices toward a more sustainable resource-harvest have provided a burgeoning market for non-timber or special forest products (Schlosser and Blatner 1995; Hansis 1998; von Hagen and Fight 1999). Special forest products include understory species such as cones, berries, mushrooms, algae, lichens, evergreen boughs, and microorganisms. These plant products are used as medicines, edibles, floral greens, and dyes and contribute $\$ 200$ million or more annually to the Pacific Northwest economy (Hansis 1998).

Demands for special forest products provide revenue-generating opportunities for processors and harvesters and for public and private landowners. Permit fees are charged for the commercial collection of resources from public lands while private landowners generate revenue by establishing lease options to extract raw materials. Although markets for special forest products have increased substantially in the past decade, little research has examined the environmental, social, cultural, and economic impacts of this industry in the Pacific Northwest. Critical information gaps are, however, beginning to be addressed by government agencies, academic researchers, and special forest product industry specialists (Craig 1998; Borsting 1998; Schlosser et al. 1992).

An estimated $29 \%$ or 16,000 plant species in the United States are at risk of extinction as a result of habitat loss and the introduction of non-native species (Robbins 
1998). Some authors suggest that increased demands for certain plant species valued by herbal and phytopharmaceutical companies, are further contributing to the loss of plant species (Masood 1997; Mead 1998; Phillipson 1997). The plight of popular herbs such as echinacea (Echinacea spp.), goldenseal (Hydrastis canadensis), American ginseng (Panax ginseng), cascara (Cascara sagrada), and Pacific yew (Taxus brevifolia), has drawn public attention to dwindling plant resources used as medicinals (Foster 1995). The unregulated harvest of medicinal plants along with increased extraction rates, and little research about plant species' responses to harvest, pose a threat to these plants and the ecosystems in which they occur.

\section{Research Objective}

Much of the research on Pacific Northwest special forest products has addressed edible fungi with respect to it's harvest, economic significance, and cultural value (Richards 1997; Hansis 1998; Luoma 1999). Medicinal plants, in contrast, have received less attention. Little research has been conducted on the size of the medicinal plant industry in the Pacific Northwest, the volume of speciesspecific harvests, and the ecological impacts of this harvest (Foster 1993). The purpose of my study is to identify the medicinal plant species that are commercially harvested from the Mount Hood National Forest, determine the amounts harvested, and determine the impact of commercial harvests on target species' densities using cover measurements. I focus specifically on four native medicinal plant species: kinnikinnick (Arctostaphylos uva-ursi), yarrow (Achillea millefolium), valerian (Valeriana sitchensis), and Oregon grape (Berberis nervosa). I chose to examine these medicinal plants because they have been harvested consistently from the 
Mount Hood National Forest for the past eight years and have botanical properties valuable to the herbal market (Buresh, pers. comm. 1999).

To meet my research objective, I interviewed herbal industry employees and Forest Service personnel and collected field data from sampling units I established in different parts of the Mount Hood National Forest. Two important underlying assumptions of my research are 1) demands for herbs will continue to increase, and 2) plant species responses to harvest, and harvest thresholds are unknown. The consequence of a growing market demand coupled with a scarcity of ecological research on the effects of plant removal, could result in over-harvest and biodiversity loss. Because little research has addressed medicinal plant harvests, my research serves as a prototype for future studies that consider commercial harvests with respect to the types of species wildcrafted and the impacts of harvest on target species cover.

This study fits into a long tradition of geographical research that examines landscape changes under human-induced influences. These human/biota interaction studies were introduced to the discipline by Carl Sauer and his students at the University of California, Berkeley. More contemporary examples of biogeographic research examines the role of humans in modifying plant communities (Veblen 1989). Berkeley trained biogeographers such as Robert Frenkel, James Parsons, Thomas Vale, Thomas Veblen and their students have studied the processes and patterns of vegetation change and the role of natural and human-induced disturbance in changing community composition and structure. These and other biogeographers frequently conduct their research in the context of conservation and resource management (Veblen 1989). My research addresses these traditions in geography by 
considering human-induced impacts on natural systems and establishing guidelines that address the sustainable use of these resources.

\section{THE PACIFIC NORTHWEST SPECIAL FOREST PRODUCTS INDUSTRY}

The special forest products industry in the Pacific Northwest is based primarily on the extraction, processing, and marketing of understory plants and plant parts. Major components of the industry include floral greens, Christmas greens, edible mushrooms, and medicinal plants (Blatner 1997; von Hagen and Fight 1999). Research on the special forest products industry of the Pacific Northwest is becoming available as the economic value of this industry is increasingly recognized (Schlosser et al. 1992; Freed 1995; Lyke and Brooks 1995; Savage 1995; Schlosser and Blatner 1995; Hansis 1998). Historically, much of the research available on special forest products has been concentrated in tropical rather than temperate regions (Lampietti and Dixon 1995; McChesney 1996; Peters 1996; Crook and Clapp 1998; Pierce 1999). Lampietti and Dixon (1995) attribute this research bias to different values placed on these resources in lesser developed versus developed countries. In lesser developed countries, special forest products are more closely associated with subsistence while in more developed countries, their uses are associated with recreation. However, the commercial value of special forest products in temperate regions, and especially in the Pacific Northwest, are increasingly being recognized by researchers, land management agencies, industry specialists and the public. Much of the regional research has been conducted west of the Cascades (Newton 1957; Schlosser et al. 1992; Savage 1995) and on the 
Washington coast (Kantor 1994; Robinson 1994; Schlosser et al. 1991), although some information about the special forest products industry in eastern Oregon is also available (Schlosser and Blatner 1997; Lipske 1994).

For centuries, native populations in the Pacific Northwest have harvested understory vegetation for consumption, medicine and shelter (Richards 1997). Commercial harvesting of floral greens and medicinals such as cascara bark began in the 1930s. In 1976, the National Forest Management Act was implemented by the U.S. Forest Service to authorize the sale of special forest products in response to their increased commercialization (Craig 1998). Increased harvest levels in the Pacific Northwest during the latter half of the 1980s are attributed to greater regional, national and international demands for new products. In addition, workers displaced by a weakened timber industry provided labor for the industry (Hansis 1998). Dwindling forest resources in other regions has also created an increased demand for Pacific Northwest products as in the export of matsutake from the Pacific Northwest to eastern Asian markets as a result of over-harvest of the "true" matsutake in that region (Molina et al. 1993).

The special forest products industry employs harvesters, processors, laboratory technicians, brokers, and marketers. Value is added to these products locally through processing, packaging and marketing. Currently, the majority of industry employees are Caucasians from rural areas previously employed in the timber industry but increasing numbers of Hispanic and Southeast Asian immigrants are seeking employment in plant harvesting (Hansis 1998). Native Americans, who have access to these resources through treaty rights, make up a small proportion of harvesters (Richards 1997). Tensions among different racial groups who collect 
mushrooms have been documented and have drawn attention to the special products industry (Hansis 1998).

Harvesters are generally self-employed, part-time seasonal workers who sell their products to processors usually on a cash-only basis. Processors dry and package the products for sale to wholesalers, brokers, or directly to retailers. An estimated 10,000 full-time and part-time employees are involved in the harvesting, processing, and marketing of special forest products in the Pacific Northwest (Savage 1995).

\section{THE MEDICINAL PLANT INDUSTRY}

Commercial harvesting of wild plants for their medicinal properties has become a viable and lucrative industry in the Pacific Northwest (Hansis 1998). In the United States, the herbal products industry is growing $15-20 \%$ annually (Robbins 1997) with an estimated one-third of Americans using alternative medicines (Marwick 1995). Herbal plant-based medicines are used in a variety of forms that include teas, extracts, oils, and capsules, and are sold in grocery stores, natural food markets, mail-order catalogs and over the internet (Brevoort 1998).

The medicinal plant industry consists of two distinct components, the herbal market and the phytopharmaceutical industry. The herbal market consists of herbs not approved by the Food and Drug Administration (FDA) and are consequently marketed as dietary supplements with no reference to specific health treatment claims. My study considers this component of the market. The phytopharmaceutical industry is composed of large pharmaceutical companies (e.g., Bristol-Meyers 
Squibb) and organizations such as the National Cancer Institute and the National Institute of Health, which use plant derivatives to develop FDA-approved drugs (Craig 1998). This component of the industry is credited with promoting the resurgence in plant-based medicinal use by investing large amounts of advertising dollars to increase consumer awareness of these products (Brevoort 1998).

Another factor that explains the increased use of herbal medicines in the United States and other western countries includes a growing skepticism about western medical treatments. The long-term effects of antibiotic use are being questioned while more holistic, preventative methods of health maintenance are being sought by American and European consumers (Tilford 1997).

Historically, plants have played a dominant role in the treatment of diseases. Until the 1820s, botanical medicines comprised two-thirds of the United States pharmacopoeia and botanicals continued as a primary means of treating disease until the early 1900s (Tilford 1997). Thereafter, modern medicine largely abandoned the use of botanicals and instead adopted synthetic forms of isolated plant compounds to emulate the disease-treating properties of specific plants.

Craig (1998) estimates that the United States herbal market generates $\$ 2$ billion annually; worldwide, revenues from this industry are estimated at $\$ 10$ billion (Freese 1998). Some 600 medicinal plant species are commonly traded in the United States (Foster 1990); worldwide, 80,000 plant species are documented as traditional medicines (Foster 1995). Top selling herbs in the United States include ginkgo (Gingko biloba), St. Johnswort (Hypericum perforatum), American ginseng, and echinacea (Brevoort 1998). Uses of these herbs include treatment for cardiovascular illnesses and circulatory disorders, depression, energy-enhancement and immune 
system function, respectively (Sears 1995; Masood 1997).

The Pacific yew (Taxus brevifolia) and cascara (Rhamnus purshiana) are two plant species from the Pacific Northwest highly valued by the medicinal industry. Their exploitation is credited with developing the regional medicinal plant industry. The discovery of taxol in Pacific yew bark in the 1980s resulted in its over-harvest. In 1996, global sales of taxol used to treat cancer exceeded $\$ 800$ million (Mead 1998). Recently, alternative methods of taxol extraction that do not involve stripping the yew bark have been developed in response to declining yew populations (Phillipson 1997) and large-scale propagation of different yew varieties is being conducted to mass produce taxol for clinical use (Joyce 1990). Cascara, a deciduous shrub found in Pacific Northwest coastal forests and riparian areas west of the Cascades, has been harvested since the 1930s for use as a laxative (Tilford 1997). Although synthetic laxatives were developed in the 1970s, three million pounds of cascara bark are harvested annually from the Pacific Northwest (Tilford 1997).

Many of the herbal companies harvesting, processing, and marketing herbs in the Pacific Northwest cultivate medicinal plants and collect wild plant species (also known as wildcrafting) for raw material. The regional revenue generated by this industry is unknown. In addition, little is known about the number of people employed in the industry and the extent to which medicinal plants are wildcrafted and cultivated. With increasing market demands for herbs, the limiting factors for the Pacific Northwest medicinal plant industry is the supply of source material and increased laws and regulations governing herb production and/or harvests. 


\section{MEDICINAL PLANT CONSERVATION}

Increased trade in medicinal herbs over the past fifty years has prompted an international response by governments and non-governmental organizations to prevent over-harvest and species extinction. In 1975, the Convention on International Trade in Endangered Species of Fauna and Flora (CITES) was established by the United Nations to address conservation issues with respect to trade in wildlife and wildlife products (Robbins 1997). CITES provides species-specific information on the international trade of medicinal plants. The exact volume of the global medicinal plant trade remains unknown as do the specific species traded (Fuller 1991; Robbins 1997). Traffic North America, a wildlife trade monitoring program of the World Wildlife Fund, is currently collecting data about the commercial trade of native North American plants in an attempt to prevent and reduce unsustainable harvest practices (Fuller 1991).

Locally, government agencies such as the U.S. Forest Service are responding to escalated medicinal plant demands by increasing research efforts and establishing permitting procedures to track harvests. The Forest Service in conjunction with the Rogue Institute for Ecology and Economy in Ashland, Oregon, is compiling an informational database of special forest products in the Pacific Northwest that includes medicinal plants, in order to inform management decisions about these products (Borsting 1998). Specifically, they are identifying plants of regional commercial importance and providing information about plant responses to disturbance, plant life histories, and plant harvest methods.

The U.S. Forest Service is also conducting a study with Lincoln County, 
Oregon, to expand the production, use, and sale of special forest products in rural communities (Newport News Times). Their objective is to identify special forest products that can be harvested for commercial or personal use in that region. Many of these joint projects integrate conservation and development. Chief among these enterprises is Rainkist, a special forest products company that in conjunction with its suppliers seeks to create economic opportunity through value-added processing, to promote social equity among harvesters, and to encourage ecologically-sound harvesting and stewardship techniques (von Hagen and Fight 1999).

The Oregon Natural Heritage program is involved in listing plants that need protection from harvest, while United Plant Savers, a national organization, is concerned specifically with the preservation of native medicinal plants. The Oregon Native Plant Society and the U.S. Department of Fish and Wildlife are other organizations concerned with endangered plant species and their conservation.

\section{MEDICINAL PLANTS OF THE MOUNT HOOD NATIONAL FOREST}

The four medicinal plant species used in my study, kinnikinnick, yarrow, valerian and Oregon grape, represent different plant families and ecosystems in the Mount Hood National Forest. Kinnikinnick, a member of the Ericaceae (Heath) family, grows on a variety of soils and is found in exposed areas of low productivity on the Mount Hood National Forest from sea-level to $1,200 \mathrm{~m}$ (Halverson et al. 1986). The entire plant is high in tannic acid and herbalists use it to treat urinary and digestive tract infections. Yarrow is an herb in the Compositae (Sunflower) family that is found in disturbed areas (resulting from logging and fire, for example) from 
lowlands to timberline east and west of the Cascades (Peck 1961). It is useful for treating circulatory diseases and the common cold. Its historical uses as a medicinal are well documented (Tilford 1997). Valerian grows in soils that retain moisture well into the summer and are high in organic matter (Tilford 1997). It is in the Valerianaceae family and is common in montane meadows and forests of the Cascades. Valerian has been used for hundreds of years to treat anxiety, muscle tension, and insomnia. Locally, native Americans crushed the root for use as an aphrodisiac (Halverson 1986). Oregon grape has a wide distribution and is found in coniferous forests up to timberline on the west side of Mount Hood (Halverson et al. 1986). As a member of the Berberidaceae (Barberry) family, it contains a strong alkaloid, berberine, which has anti-microbial qualities used to fight infections. Berberine is also known to stimulate bile production for use in treating liver and digestive disorders. The dwarf Oregon grape, which has been listed as a "to watch" species by United Plant Savers, has been used recently as an alternative to goldenseal for fighting infections.

These four plant species are harvested, processed, and marketed as herbal supplements primarily in local natural food stores. Although their distributions are widespread in the Mount Hood National Forest, harvesting for the herbal trade is just one of many potential perturbations that may affect the long-term status of these species. For this reason, it is important to establish the sustainability of this resource harvest, identify which medicinal plant species are extracted for the herbal trade, and determine the harvest locations. Because the Mount Hood National Forest encompasses a large area with a lot of road access, it is impossible to prevent illegal harvests, thereby making it difficult to determine total harvest yields from this area. 


\section{Thesis Outline}

My thesis is divided into the following chapters: study area, methodology, results, discussion, and conclusions. The study area section identifies the climate, geology, and vegetation zones of Mount Hood National Forest and describes my various study sites. My methodology section details the qualitative and quantitative data collection and analytical methods I use to identify procedures, policies, and impacts of medicinal plant harvests on Mount Hood National Forest. My results include a summation of the Forest Service and herbal company employee interviews along with the statistical results from my field sampling. My discussion addresses the implications of these results. In my conclusion I provide industry and administrative recommendations for ensuring the sustainability of these botanical resources, and reiterate my qualitative and quantitative findings. 


\section{STUDY AREA}

My field work was conducted at four sites in the Mount Hood National Forest, located in the Cascade Mountain Range of northern Oregon. Mount Hood National Forest encompasses 1.2 million acres and is bounded to the east by the Deschutes River Valley, to the west by the Willamette Valley, and to the north and south by the Columbia River and the Willamette National Forest, respectively. There are four Forest Service Ranger Districts on the Mount Hood National Forest, Zigzag, Barlow, Hood River, and Clackamas-Estacada. My sample sites are located in the Zigzag, Barlow, and Clackamas-Estacada Ranger Districts, representing areas east and west of Mount Hood (Figure 1).

\section{Climate and Vegetation}

The north-south orientation of the Cascade Range creates a barrier between westerly maritime air masses and cool northeasterly continental air masses. Maritime air masses cool as they reach the higher elevations of the Cascade Range, resulting in high precipitation on the west side of the Range. Adiabatic warming and a subsequent decrease in relative humidity results in a rainshadow east of the Range. This orographic effect contributes to a wide range of climate and vegetation zones in Mount Hood National Forest. Total annual precipitation at the sample sites west and east of Mount Hood ranges from 211 to $30 \mathrm{~cm}$, respectively 


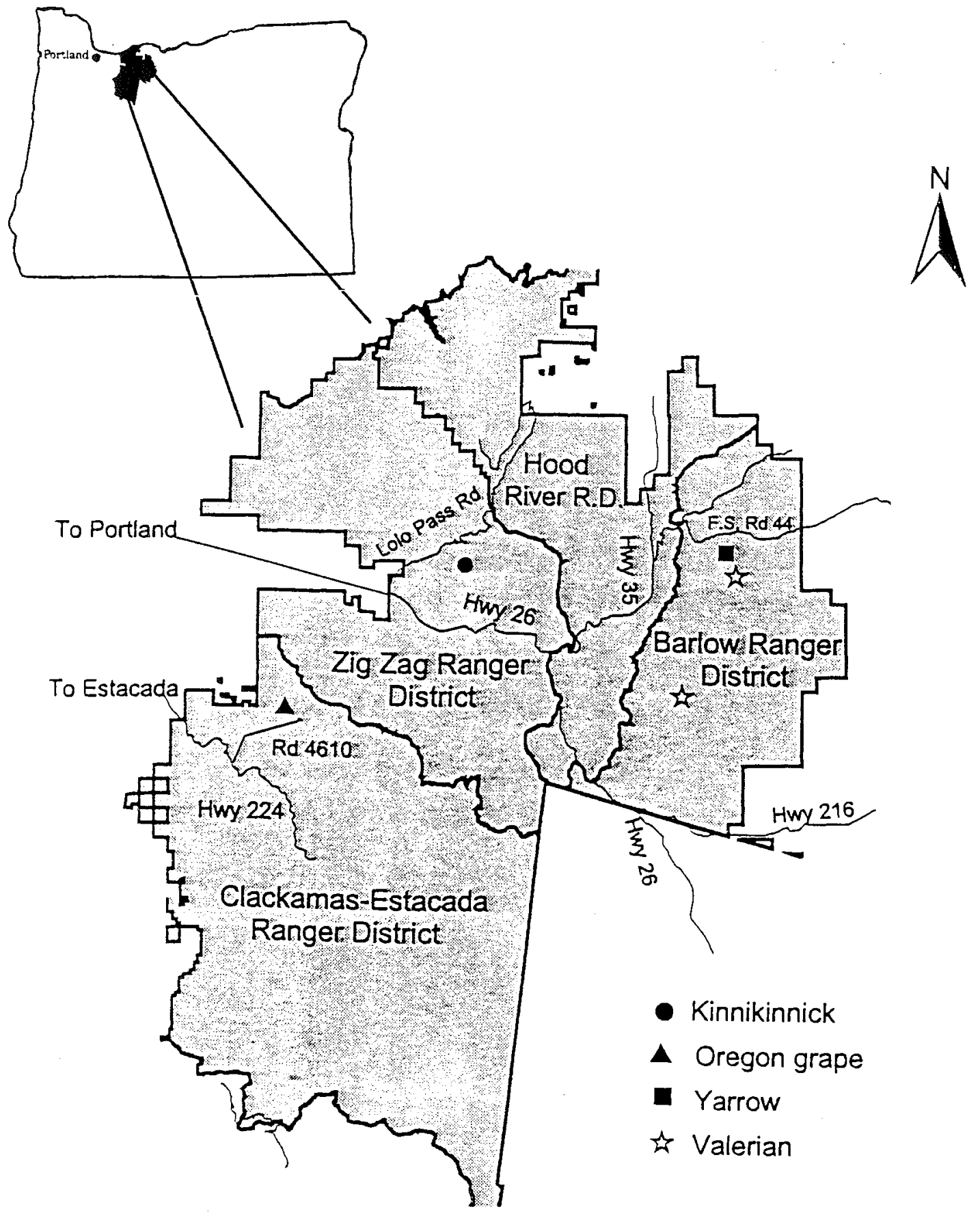

0 40 Kilometers

Figure 1. Study Sites on Mount Hood National Forest, Oregon. 
(National Weather Service). Precipitation varies with elevation and occurs primarily during the winter, mainly as snow above $1,000 \mathrm{~m}$. Snow accumulation ranges from $165 \mathrm{~cm}$ at $300 \mathrm{~m}$ elevation to $356-432 \mathrm{~cm}$ at $1,500 \mathrm{~m}$ elevation. At my study sites east of Mount Hood, precipitation occurs mostly as snowfall, averaging $58-140 \mathrm{~cm}$ annually (National Weather Service). The mean snow depth is approximately $6 \mathrm{~cm}$. My study sites west of Mount Hood experience precipitation mostly in the form of rain (160-211 cm total annual precipitation). The mean snow depth during the winter months at these sites is approximately $3 \mathrm{~cm}$. Mean annual temperatures at the different sample sites are within $\sim 10^{\circ} \mathrm{C}$; temperature ranges east of Mount Hood are greater (National Weather Service). The summer months tend to be warm and dry.

The Mount Hood National Forest is dominated by a variety of conifer species. The major forest zones of the Mount Hood National Forest include the Western Hemlock (Tsuga heterophylla), Pacific Silver Fir (Abies amabalis), and Mountain Hemlock (Tsuga mertensiana) Zones. The Western Hemlock Zone is widespread, occurring mostly on the west side of Mount Hood from sea level to $1,000 \mathrm{~m}$. It includes western white pine (Pinus monticola) on the east side of the Cascade Range between 800-1200 m. Western hemlock shares much of its range with Douglas-fir (Pseudotsuga menziesii) and western red cedar (Thuja plicata). Understory dominants in this zone include salal (Gaultheria shallon) on drier sites 
and Oregon grape (Berberis nervosa) and sword fern (Polystichum munitum) on mesic sites (Franklin and Dyrness 1988).

The Pacific Silver Fir Zone occurs primarily on the western slopes of Mount Hood at elevations of $1,000 \mathrm{~m}$ to $1,500 \mathrm{~m}$. This zone includes noble fir (Abies procera) and subalpine fire (Abies lasciocarpa) as the co-dominant tree species. Understory species typically include Pacific rhododendron (Rhododendron macrophyllum) and black huckleberry (Vaccinium membranaceum). The Mountain Hemlock Zone is the highest forested zone along the western slopes of Mount Hood (1,200-1,800 m). This zone has an understory similar to that of the Pacific Silver Fir Zone but also includes fool's huckleberry (Menziesia ferruginea) and false hellebore (Veratrum viride). The Ponderosa Pine (Pinus ponderosa) Zone occupies a narrow band on the eastern flanks of Mount Hood. This dry zone includes understory species such as antelope brush (Purshia tridentata) and snowbrush (Ceanothus velutinus) (Franklin and Dyrness 1988).

\section{Geologic History}

Mount Hood National Forest lies within the High Cascades Geomorphic Province. The High Cascades originated during the Pliocene (5 to 1.8 million YBP) and Pleistocene (1.8 to 11,000 YBP) epochs as a result of uplift and subduction of tectonic plates and massive outpourings of lava from shield volcanoes and cinder cones (Orr et al. 1992). The topography of this geologically young region can be attributed to recent uplift, weathering, volcanic activity, and 
glaciation which carved out glacial valleys, dammed lakes and eroded major peaks (Orr et al. 1992). The high levels of volcanic activity that characterize the Pliocene and Pleistocene epochs resulted in extensive deposits of extrusive igneous rocks that comprise a majority of the bedrock in Mount Hood National Forest (Howes 1979). More recently, lahars, pyroclastic flows, and debris avalanches produced by eruptions of Mount Hood have further altered the topography and geomorphology of the area (Cameron and Pringle 1986).

\section{$\underline{\text { Study Sites }}$}

The kinnikinnick study sites are located on the Zigzag Ranger District in the Old Maids Flat area east of Lolo Pass Road (Figure 1). These sites lie adjacent to the north side of Forest Service Road 1825, where it meets Forest Service Road 380 to Riley Campground, $\sim 10 \mathrm{~km}$ from Zigzag. The kinnikinnick and lodgepole pine (Pinus contorta) community type at this site is atypical of the surrounding forest and occupies a 170-220 year old lahar deposit from eruptions of Mount Hood (Cameron and Pringle 1987). The kinnikinnick populations at this site are dense along the roadside where there is more exposure to sunlight. In the forest interior, populations become more sporadic and less dense, and are associated with gaps in the forest canopy. Mean annual precipitation at the kinnikinnick site is higher than the other sample sites $(211 \mathrm{~cm})$ (National Weather Service).

The yarrow sites are located at approximately $1,900 \mathrm{~m}$ in the Barlow Ranger District east of Mount Hood (Figure 1). The Flag Point harvest and control 
sites are located south of Forest Service Road 44 at the juncture of Forest Service Road 200 and Road 2730. The Denest Spring sites are located off of Road 2730 on Road 240. All yarrow sites are in clearcuts created and underburned in 1984 (Sonnabend, pers. comm. 2000). Western larch (Larix occidentalis) and ponderosa pine saplings have colonized these sites along with yarrow, whose distribution at these sites is generally sparse. Mean annual precipitation is lower at these sites ( 30 $\mathrm{cm})$ than the kinnikinnick sites because of their location east of Mount Hood.

The valerian sites are also located on the Barlow Ranger District (Figure 1). The Bulo Point site is close to the yarrow sites while the Grasshopper Point study area is directly south of the Badger Creek Wilderness. The Grasshopper Point sites are located north of Highway 216 off of Forest Service Road 4860. The plots are at an elevation of $1,500 \mathrm{~m}$ in a 1979 clearcut (Sonnabend, pers.comm. 2000). Fifteen to twenty year old noble fir and western white pine have become established on this site. The valerian distribution at this site and the Bulo Point location is highly clumped and sparse. The Bulo Point site is located west of Forest Service Road 4450 on Road 150 . This site is located on a $15^{\circ}$ slope at $1,400 \mathrm{~m}$ in a 1981 clearcut (Sonnabend, pers. comm. 2000). The plots at this site are adjacent to an intermittent creek.

The Oregon grape sites are located at 1,250 m on the Clackamas-Estacada Ranger District north of Highway 224, adjacent to Forest Service Road 4610 (Figure 1). The understory at this site is dense with Oregon grape, sword fern and 
salal. The overstory is comprised of young, $40 \mathrm{~m}$ tall western hemlock. The mean annual precipitation at this site is $153 \mathrm{~cm}$. 


\section{CHAPTER III}

\section{METHODOLOGY}

My methods were selected to meet various objectives; to identify and evaluate Forest Service procedures and policies regarding medicinal plant harvests on the Mount Hood National Forest, to identify the medicinal plants harvested on the Forest, and measure the effects of harvesting using cover estimates of target medicinal plant species. During my interviews I asked Forest Service personnel about the regulation and administration of medicinal plant harvests, and asked harvesters and producers of medicinal plant products to identify harvest locations, the types of plants they extract, and to provide information about the industry. I also established field plots to statistically measure and compare post-harvest and non-harvest vegetation structure for four target medicinal plant species. The statistical analysis of my field data consisted of descriptive and comparative summaries of the cover estimates collected from my target species control and harvested plots.

The field sampling component of this study was used to estimate changes in cover of target species (kinnikinnick, yarrow, valerian, and Oregon grape) after harvest and to provide opportunities to monitor plant responses to harvest over time. Field work involved reconnaissance of sample sites for the four target species, developing sampling methods relevant to the species' distributions and harvest techniques, and 
collecting cover data. Harvest sites for the target species were chosen according to where the harvesters extracted these plant materials. I located control sites close to the harvest sites in order to maintain similar environmental conditions among the control and harvest sites. I used cover measures in this study because they are sensitive to changes in plant mortality, recruitment and vigor (Elzinga et al. 1998). I established permanent plots at all sites to provide opportunities for future monitoring.

\section{INTERVIEWS}

\section{Forest Service Personnel}

The U.S. Forest Service special forest products programs are administered independently by the four ranger districts on the Mount Hood National Forest. I interviewed Special Forest Product Coordinators from the Barlow, Hood River, Zigzag and Clackamas Districts to obtain information about district medicinal plant permitting regulations and guidelines for commercial extraction (Appendix A). I also examined permit records at three of the four districts to identify companies extracting medicinal plants and to determine the medicinal plants being harvested. I did not examine the Hood River Ranger District's permit records as they do not have a program for administering commercial medicinal plant harvests (Jones, pers. comm. 1999). During my interviews, I reviewed medicinal plant harvest maps at the Zigzag, Barlow, and Clackamas-Estacada Ranger Districts. These maps identify 
recommended harvest areas for each of the participating districts and are distributed to harvesters when they obtain a permit at the district offices. I reviewed these maps to locate harvest areas and I obtained permission to establish permanent sampling sites from the Special Forest Products Coordinators at the Zigzag, Barlow, and ClackamasEstacada Ranger Districts.

\section{Herbal Producers/Harvesters}

I interviewed employees at two herbal companies in order to identify the medicinal plants commercially harvested from Mount Hood National Forest and obtain information regarding specific plant extraction methods, harvest locations, and quantities of plants extracted (Appendix B). Company records were reviewed to obtain harvest data from prior years. The owner of one of the herbal companies notified me of harvest days so I could accompany his employees to harvest sites for field sampling. The identities of some interviewees are confidential in accordance with Portland State University's Human Subjects Agreement.

\section{FIELD METHODS}

In this section, I provide information about the different field sampling including the methods used to locate or re-locate harvest and control plots. I also describe how I measure cover changes for each of the four species. 
Arctostaphylos uva-ursi (kinnikinnick)

I accompanied harvesters from a local herb company to the kinnikinnick site to observe their method of extraction and locate specific harvest areas for sampling. The site is easily accessed by vehicle and is recommended by the Zigzag Ranger District as a site for harvest (Figure 1). Harvesting and sampling of kinnikinnick were conducted in August 1999 immediately adjacent to the road-side in an area that extended into the forest approximately $15 \mathrm{~m}$.

Kinnikinnick cover estimates were recorded for harvested and unharvested (control) areas, and for areas harvested before 1999. Previously harvested areas that bordered the August 1999 harvest areas were identified by cut stem-tips that were darker, more brittle, and more weathered than the freshly harvested stems. I also established control plots in the forest interior paralleling the harvest sites and farther east along Rd. 1819, immediately adjacent to the road. Kinnikinnick control areas were identified by having no cut stem-tips.

A rigid one-meter square quadrat divided into four equal squares $(.25 \mathrm{~m}$ by .25 m), was subjectively placed in thirty different locations for each of the harvest, control, and previously harvested areas. Subjective placement of the quadrats was necessary because the kinnikinnick distribution in this area is highly clustered, and the specific areas of harvest and non-harvest are evident. I recorded visual estimates of kinnikinnick cover as percentages for each quadrat. To ensure the reliability of this method, test runs were conducted with cover estimates compared among myself and 
four field assistants. Subsequent cover estimates at other field sites for other species were conducted by two collectors who took an average of the two estimates for each quadrat. An estimated $70 \%$ of the harvested area was sampled. Cover data for harvested and non-harvested kinnikinnick areas were compared to determine changes in post-harvest cover. For areas harvested in previous years, I noted the status of the harvested stems. Kinnikinnick cover percentages were converted into cover classes (Jensen et al. 1994) for statistical analysis (Elzinga et al. 1998).

Visible evidence of harvesting impacts such as trampling were recorded for the harvest areas. Other uses of the area by horseback riders, hikers, and campers were also noted. Geographic Positioning Systems (GPS) readings were recorded to facilitate the re-location of the sample areas and to accompany the site maps used to provide directions from the nearest highway to the site.

Stem height measurements were sampled for kinnikinnick in the August 1999 harvest and control quadrats to determine compliance with Forest Service harvest recommendations. A total of 300 cut and uncut stem measurements were recorded for the harvest and control quadrats. Cut and uncut stems within the quadrats were randomly chosen and measured from the top of the stem to the ground. Average heights were compared for harvested and non-harvested stems to determine approximate stem-height cuts. Measurements were taken using a standard ruler and recorded in centimeters. 


\section{Achillea millefolium (yarrow)}

The four yarrow sites are located east of Mount Hood in the Barlow Ranger District (Figure 1). These sites were identified by the owner of an herbal company who has extracted yarrow from this area for several years. Yarrow harvests and field work were conducted in September 1999. One of the harvest sites had not been harvested prior to September 1999. Two harvested and two control sites at Flag Point and Denest Spring were examined and are located within $11 \mathrm{~km}$ of each other.

I established fifty-by-fifty meter macroplots at each of the four yarrow sites. Within the macroplots, one meter square sample quadrats were located using a random numbers table (Elzinga et al. 1998). Cover measures for all species were recorded for each quadrat.

The frequently harvested Flag Point site was sampled using 122 randomly placed quadrats to determine yarrow cover. Three-foot long permanent rebar markers were placed in the northeast and southwest corners of the macroplot for permanent monitoring of the yarrow populations. Locational and elevational readings were taken at every corner of the macroplot using GPS, and site maps were drawn to facilitate relocation. Photographs were also taken from each corner of the plot and logged to facilitate re-locating the macroplot corners.

Similar data were collected for the Flag Point control macroplot using 30 randomly placed quadrats. Thirty quadrats were selected as a representative sample for statistical analysis of the cover estimates. This control site lies 250 meters west of 
the harvest site, and was marked with rebar in the southeast and northwest corners of the plot.

I recorded yarrow cover in 110 randomly placed quadrats at the Denest Spring harvest site. This site was identified by an herbal company owner as a yarrow site not harvested prior to the summer of 1999. Rebar was placed in the northeast and southwest corners and GPS readings were recorded. The control site, located 1/2 km to the north, was randomly sampled using 30 one meter square quadrats. Associated species were noted to ensure similar species composition between the control and harvest sites. Rebar was placed in the northeast and southwest corners to permanently mark the control macroplot.

\section{Valeriana sitchensis (valerian)}

I was able to use data from a valerian monitoring study initiated by a botanist at the Barlow Ranger District in 1995 that had been implemented in response to the high demand for valerian by commercial producers. In this earlier study, two sites were established at Grasshopper Point and Bulo Point on the Barlow Ranger District. Five $1 \mathrm{~m}$ square quadrats were established at Grasshopper Point and subjected to varying degrees of valerian harvest in October 1995; two quadrats (A and D) were not harvested, $50 \%$ of the valerian was harvested from another plot (C), and 100\% was harvested from the remaining quadrats, B and E. Valerian harvest from the sample plots was deliberate in order to determine the species response to varying degrees of 
harvest over time. Valerian cover was estimated and recorded in percentages for all of the quadrats prior to harvest in October 1995 and September 1997. Cover data for associated species were also recorded. The Forest Service did not collect additional data for this project after 1997 because of budget restrictions and personnel turnovers and no analyses had been conducted on the 1995 and 1997 data.

In October 1999, I re-located most of the quadrats at the Bulo Point and Grasshopper Point sites. At the Grasshopper Point site, I re-located four of the five quadrats marked with pin flags. I analyzed the site-maps to identify the control and harvested quadrats. I re-sampled the quadrats, obtaining cover estimates for valerian. These data were compared to the Forest Service data to determine changes in cover from 1995 to 1999 . Site maps were re-drawn in order to facilitate relocating these plots and rebar was placed in the southeast corner of each quadrat. Red pin flags were placed in the remaining three corners of each of the quadrats. GPS readings were taken and site photographs identify the sample areas.

I collected similar data for two of the four quadrats at the Bulo Point site. Two of these quadrats, $\mathrm{A}$ and $\mathrm{D}$, had all of the valerian population harvested. Plots $\mathrm{B}$ and $\mathrm{C}$ had 50\% harvested, and none of the valerian harvested, respectively. Plots $\mathrm{A}$ and $\mathrm{C}$ could not be re-located for sampling in 1999. I placed pin flags to mark the corners of quadrats B and D and drew a site map detailing the quadrats' locations.

I obtained permit data on commercial valerian extraction from the Barlow Ranger District and reviewed permit acquisition records to determine the amounts of 
valerian harvested legally on the District. I compiled these data for 1991 through 1998.

\section{Berberis aquifolium (Oregon grape)}

I located my study site for Oregon grape by accompanying a group of harvesters to the site in October 1999. This site is located south of the Salmon Huckleberry Wilderness area on Forest Service Road 4610. Harvest of the Oregon grape occurred on the north side of the road and was confined to an area approximately $3 \mathrm{~m} 540 \mathrm{~m}$, between the road and a steep slope. Because the extraction of Oregon grape was intensive between the road and the slope, sampling was done along a $37 \mathrm{~m}$ transect placed parallel to the road. Visual cover estimates of Oregon grape were recorded for 37 one meter square quadrats placed north and south of the transect line every other meter. Associated species within the quadrats were noted.

A control site with the same number of quadrats (37) was established 20 m east of the harvest area. The control site was located with the aid of a harvester who confirmed that no Oregon grape extraction had occurred at the site. Cover estimates of Oregon grape were recorded for quadrats placed every other meter north and south of the transect line. The transect line was marked by flagging at the east and west ends of the line. A detailed site map was drawn with distances from the road to different points along the transect. 
I took GPS readings for the east and west ends of the harvest and control transect lines. Photographs of harvesters were taken to demonstrate the method of Oregon grape extraction. Photographs of the harvested and control quadrats were also taken for comparison.

\section{STATISTICAL ANALYSIS}

For the kinnikinnick data, descriptive statistics (mean, median, range) and comparative statistics (Kruskal-Wallis test) were calculated for percent cover data collected from the sample quadrats. These analyses summarize and compare the variance in percent cover within and between the 1999 harvested, control, and previously harvested quadrats. The Kruskal-Wallis test is a non-parametric test used to analyze the variance between the means of three or more samples (Burt and Barber 1996). The cover class data were analyzed using the Chi-square test that is appropriate for nominal data. This test statistic is used to compare observed and expected frequencies when individual quadrats are the sampling units (Burt and Barber 1996). The data from the two methods of analysis were compiled and compared to determine the robustness of the results.

For yarrow, summary and descriptive statistics were calculated for all of the sample quadrats at all sites. Cover estimates for the harvest and control quadrats at the Flag Point and Denest Spring sites were analyzed using the Mann-Whitney test, a non- 
parametric test used to compare two independent samples (Burt and Barber 1996).

The cover data were re-coded into cover classes which were analyzed using the Chisquare test to determine whether there is a significant relationship between the frequency ratings of the control and harvest sites. The Oregon grape cover data was subject to the same statistical analysis as the yarrow, and results are provided for the cover estimate data and the cover class frequencies.

The data collected at the valerian sites were not analyzed statistically as the sample size was inadequate however, I compared cover estimates for all of the years to determine changes in cover in the quadrats over time. 


\section{CHAPTER IV}

\section{RESULTS}

In this chapter I present the qualitative results of my interviews with herbal producers/harvesters and Forest Service representatives and the statistical results of my vegetation analysis. Field sampling results and results from my statistical analyses are presented to determine harvest affects and compliance with Forest Service guidelines. The results are presented separately for each harvested species because the sampling methods and statistical tests for the cover estimates differed for each. Field results from the valerian portion of my study are included with the Forest Service interview data, as they were not statistically analyzed.

\section{INTERVIEWS}

\section{$\underline{\text { Producers/Harvesters }}$}

Producers/harvesters were interviewed to gain a greater understanding of the regional herbal medicinal industry and to obtain information specific to medicinal plant harvests. Interviewees were employees of two botanical herb companies that engage in wildcrafting on the Mount Hood National Forest. For one company, the owner, lab specialist, harvesters and the harvest manager were interviewed. Interviewees from the second company included the farm manager, purchasing manager and the extraction 
lab manager. These companies have operated locally for a combined total of 24 years and employ seventy full-time cultivators, wildcrafters, processors, shipping staff, and administrators. Additional wildcrafters are contracted seasonally as needed. Facilities at both companies include cold storage units and dryers for freeze-drying the herbs to maintain their natural potency and increase their shelf-life.

\section{Survey Results}

Markets for the processed herbs are mostly domestic; international exports include sales to Canada and Great Britain. Neither company harvests or processes special forest products other than medicinals. Approximately $60 \%$ of the herbs processed by the two companies are locally cultivated with the remaining $40 \%$ collected on public and private lands. Each company cultivates up to ninety different herbs, some of which include species having dwindling wild reserves such as echinacea, cascara, American ginseng, and valerian (Mead 1998; Foster 1993). Herbs are also imported from Hawaii and Australia. The two companies harvest 15-20\% and $30 \%$ of their wildcrafted herbs respectively from the Mount Hood National Forest. The remaining plants are harvested from national forests in eastern Oregon, Washington, and Idaho.

Herbs extracted from the Mount Hood National Forest include valerian, Oregon grape, pipsissewa (Chimaphila umbellata), kinnikinnick, yarrow, arnica (Arnica latifolia), and desert parsley (Lomatium dissectum). Harvest yield data for 
1997 and 1999 were made available by only one company ${ }^{*}$ (Table I). Yields for 9 of the 11 commonly harvested species on the Mount Hood National Forest vary considerably on an annual basis. For example, Oregon grape harvest yields increased by 390 pounds (fresh weight) from 1997 to 1999, whereas valerian and kinnikinnick harvests decreased significantly for the same period (Table I).

\section{TABLE I}

\section{MEDICINAL PLANTS EXTRACTED FROM THE MOUNT HOOD NATIONAL FOREST (YIELDS ARE POUNDS IN FRESH WEIGHT)*}

\begin{tabular}{|l|l|l|c|c|}
\hline Plant & $\begin{array}{l}\text { Plant part } \\
\text { harvested }\end{array}$ & Harvest Season(s) & $\begin{array}{c}1997 \\
\text { yields }\end{array}$ & $\begin{array}{c}1999 \\
\text { yields }\end{array}$ \\
\hline Desert parsley (Lomatium dissectum) & Root & Summer/Fall & - & 127 \\
Kinnikinnick (Arctostaphylos uva-ursi) & Leaf & Summer/Fall & 800 & 282 \\
Oregon Grape (Berberis aquifolium) & Root \& leaf & Summer/Fall/Winter & 600 & 989 \\
Pipsissewa (Chimaphila umbellata) & Leaf & Spring/Summer/Fall & 400 & 130 \\
Valerian (Valeriana sitchensis) & Root & Summer/Fall & 500 & 45 \\
Yarrow (Achillea millefolium) & Flower & Summer/Fall & - & 300 \\
Usnea (Usnea barbata) & Whole plant & Spring/Summer & - & - \\
Mullein (Verbascum thapsus) & Flowers/Leaf & Spring/Summer & 750 & - \\
Devil's Club (Oplopanax horridum) & Root & Summer/Fall & 50 & - \\
Arnica (Arnica latifolia) & Flowers & Summer & 300 & - \\
Lobelia (Lobelia inflata) & Tops & Summer & & \\
& & & & \\
\hline
\end{tabular}

* Table does not include all medicinal plants extracted from the National Forest

The harvest locations tend to be re-visited yearly as long as plant densities remain high. Harvest locations include those recommended by the Forest Service and locations selected by company employees. According to one of the herbal company owners, Forest Service employees notified his company of clear-cutting operations so

\footnotetext{
" The other company involved in my study would not provide yields
} 
the harvesters could remove medicinal understory plants prior to timber harvest. The owner also noted that these timber-cut sites often become future wildcrafting areas as many of the desired herbs such as yarrow, arnica, and desert parsley are early colonizing species.

Both companies participating in the survey had acquired commercial harvesting permits from the district Forest Service offices. Harvesters are required to obtain permits from the ranger district in which the plant extraction occurs. Harvest permits specify yield amounts, harvest locations, effective dates, and permittee contact information. Permit prices vary according to the species being harvested. According to the herbal company employees, many of those who wildcraft on the Mount Hood National Forest are not obtaining the necessary commercial permits, especially those who have informal arrangements to supply herbs to various herbal-supplement companies.

The two surveyed companies have wildcrafting standards in place to provide guidelines for sustainable harvests and criteria for obtaining high quality herbs. These guidelines include restrictions on harvest amounts in a given area (i.e., $\leq 30 \%$ of the total population), harvesting in the right time of year, and replanting root crowns and seeds, where appropriate. Criteria for assuring high quality herbs include extraction $100 \mathrm{~m}$ or more from well-traveled roads, railroad or main power lines, and no exposure to agricultural herbicides, pesticides or chemical fertilizers during the previous three years. 
Employees of one company demonstrated harvesting techniques for the four species included in this study. The entire Oregon grape plant is extracted by hand to get the root and all parts of the plant up to the first leaves. The leafy parts are removed, the root is washed, chipped and then dried. Oregon grape harvests are usually conducted in the fall when wet soil conditions allow for easy extraction. The extraction of valerian is similar although harvesters use pick axes to harvest the root. Yarrow and kinnikinnick harvests do not involve the extraction of the whole plant. For yarrow harvests, the inflorescence is removed while the top $5-7 \mathrm{~cm}$ of the kinnikinnick is removed using cutting shears.

\section{Forest Service Employees}

I interviewed Forest Service Special Forest Products Coordinators to obtain information about the administration and enforcement of commercial medicinal plant harvests on the Mount Hood National Forest. The four ranger districts on Mount Hood National Forest, the Barlow, Zigzag, Clackamas, and Hood River, administer their special forest products programs independently.

In 1994, ranger districts began issuing permits for special forest products in response to increased demands for non-timber forest resources. Of the total special forest products permits issued, few are requests for medicinal plants. Data on the revenue generated from medicinal plant permit sales were not available except for the Clackamas Ranger District which generated approximately \$200 in 1996. 
The Barlow, Zigzag, and Clackamas Ranger Districts have established permitting procedures for issuing medicinal plant permits and have methods for monitoring plant harvest areas. The personnel responsible for issuing permits at the districts are the Special Forest Products Coordinators and/or Timber Sales Coordinators. The special forest products program at Mount Hood National Forest is funded mostly by timber sales. Permit costs are specific to the plant species requested and the amount. These established prices are available in the Mount Hood Standard Rates Guide and are reviewed annually by Forest Service personnel to reflect changes in the market.

The plant permits are issued as Miscellaneous Non-convertible Forest Product Removal Permits and identify the plant species requested, quantities, costs, dates of harvest, and harvest locations. The Zigzag and Clackamas Ranger Districts provide maps with the permits that specify different harvest locations in order to prevent overharvesting. Additional requirements stipulated in the permits include harvesting a maximum of $50 \%$ of the existing plants within a harvest area, wildcrafting $50-100$ feet from roads, creeks and rivers, and removing plant material without the use of tools except to cut stems or branches. Examples of species-specific harvesting regulations include removing only the top three inches of the kinnikinnick plant, harvesting only the aerial parts of the pipsissewa (Chimaphila umbellata), and extracting no more than $1 / 3$ of the total coltsfoot (Petasites frigidus) found in a harvest area. Wildcrafting is not permitted in National Forest wilderness areas, botanical areas or research natural areas. 
Plant monitoring in the Clackamas Ranger District is preformed by the Special Forest Products Coordinator to ensure no sensitive plant species are present prior to approving a harvest location. This is seldom done by other districts on Mount Hood National Forest because of budget constraints and personnel shortages. Other forms of monitoring include patrolling areas of the Forest to prevent illegal harvests and issuing moratoriums on the extraction of specific plant species. For example, the Barlow Ranger District imposed a 6 year moratorium on valerian extraction beginning in 1999. The harvest restrictions were implemented in response to large increases in the demand for valerian. In 1995, permits were issued for the extraction of 1,200 pounds (fresh weight) of valerian; this increased to 2,175 pounds (fresh weight) in 1998 (Table II).

TABLE II

POUNDS OF VALERIAN HARVESTED FROM THE BARLOW RANGER DISTRICT FROM 1990-1998 (DRY WEIGHT)

\begin{tabular}{|l|l|l|l|l|l|l|l|l|}
\hline 1990 & 1991 & 1992 & 1993 & 1994 & 1995 & 1996 & 1997 & 1998 \\
\hline 400 & 400 & 425 & $\begin{array}{l}\text { No } \\
\text { data }\end{array}$ & 1,100 & 1,200 & $\begin{array}{l}\text { None } \\
\text { issued }\end{array}$ & 600 & 2,175 \\
\hline
\end{tabular}

In response to the high demand for valerian, a field study supervised by a Forest Service botanist at the Barlow Ranger District was conducted to monitor valerian regeneration. Data collected for this study are included here (Table II) but are not statistically analyzed because of insufficient data. Although no statistical 
conclusions regarding valerian regeneration can be drawn from the field study, valerian cover percent decreased post-harvest for all sample plots from 1995 to 1999 (Table III). Valerian cover in harvested plots, however, was lower than in the control plots (Figure 3).

TABLE III

VALERIAN COVER ESTIMATES FOR THE GRASSHOPPER AND BULO POINT SITES (IN PERCENTAGES)

\begin{tabular}{|l|c|c|c|}
\hline $\begin{array}{l}\text { Site } \\
\text { Grasshopper }\end{array}$ & $\begin{array}{c}\% \text { cover } \\
1995\end{array}$ & $\begin{array}{c}\% \text { cover } \\
1997\end{array}$ & $\begin{array}{c}\% \text { cover } \\
1999\end{array}$ \\
\hline Plot A- Control & 20 & 35 & 30 \\
Plot D- Control & 25 & 28 & 3 \\
Plot B- 100\% Harvested & $30^{\star}$ & 5 & 5 \\
Plot E- 100\% Harvested & $40^{*}$ & 20 & 0 \\
Plot C- 50\% Harvested & $30^{*}$ & 2 & 1 \\
\hline Bulo Point & & & \\
\hline Plot C- Control & 30 & 30 & No data** \\
Plot A- 100\% Harvested & $5^{\star}$ & No data** & No data** \\
Plot D- 100\% Harvested & $3^{*}$ & 4 & 2 \\
Plot B- 50\% Harvested & $15^{\star}$ & 20 & 10 \\
\hline prior to harvest & **sample plot could not be re-located
\end{tabular}




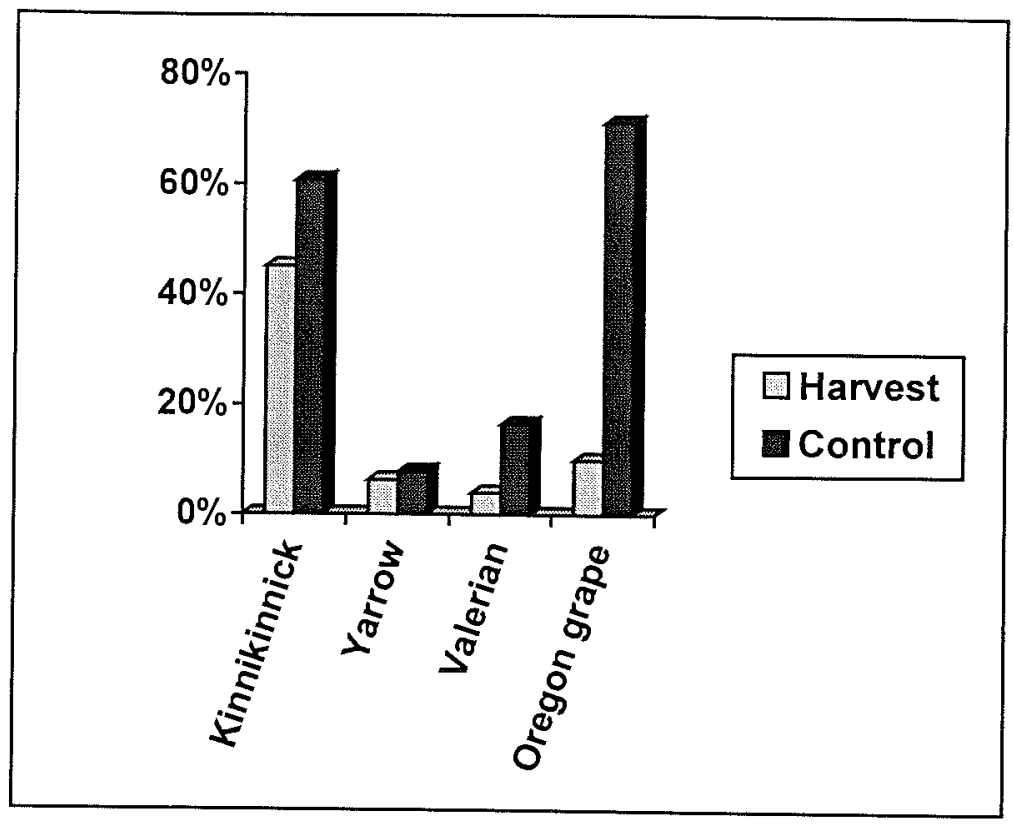

Figure 2. Estimated cover for harvested and control plots. Valerian data compares 1999 harvest and control measures.

\section{STATISTICAL RESULTS}

I analyzed cover percent data for harvested and non-harvested sites to determine whether differences exist between the sites and whether those differences are statistically significant. Results are presented by species as methods of data collection and statistical analysis differed for each. A comparative analysis of the results can therefore not be conducted. 
$\underline{\text { Kinnikinnick }}$

Descriptive statistics were determined from cover estimates of kinnikinnick at all sites. Cover measures were taken for 30 quadrats in each of the four different site types; harvested, previously harvested, and two control sites (Table IV). The KruskalWallis test results show a significant difference in cover between the different sitetypes $(\mathrm{F}=7.653 ; \mathrm{P}=0.001)($ Table $\mathrm{V})$.

TABLE IV

DESCRIPTIVE STATISTICS FOR KINNIKINNICK SAMPLE PLOTS

\begin{tabular}{|l|c|c|c|c|}
\hline Site & N & $\begin{array}{c}\text { Cover } \\
\text { Mean (\%) }\end{array}$ & SD & Cover Range (\%) \\
\hline Harvested & 30 & 41.32 & 16.61 & $18-77$ \\
\hline Previously Harvested & 30 & 48.95 & 18.19 & $25-88$ \\
\hline Control I & 30 & 60.55 & 22.42 & $25-97$ \\
\hline Control II & 30 & 60.85 & 17.6 & $28-86$ \\
\hline
\end{tabular}

TABLE V

ANAYLYSIS OF VARIANCE RESULTS FOR KINNIKINNICK

\begin{tabular}{|l|c|c|c|}
\hline Cover \% & df & F & Sig. \\
\hline Between Groups & 3 & 7.653 & 0.001 \\
\hline Within Groups & 116 & & \\
\hline Total & 119 & & \\
\hline
\end{tabular}


A Post Hoc analysis was conducted to reveal where differences between the four site-types occur. The harvested site cover is significantly different from the cover of the two control sites ( $\mathrm{P}=0.001$, Bonferroni). Kinnikinnick cover in the harvested site is significantly lower than the control sites (Figure 3). No significant differences $(\mathrm{P}<0.05)$ occur between the previously harvested and the other site-types (Table VI). A majority of the harvested plots (70\%) have between $0-45 \%$ kinnikinnick cover. This contrasts with with control sites I and II, where a majority of the plots, $67 \%$ and $77 \%$ respectively, have between $45-100 \%$ kinnikinnick cover.

\section{TABLE VI}

\section{RESULTS FOR THE KINNIKINNICK POST-HOC TESTS (BONFERRONI)}

\begin{tabular}{|l|l|c|c|}
\hline \multicolumn{3}{|c|}{ Site } & Mean \\
\multicolumn{3}{|c|}{ difference } & Sig. \\
\hline Harvested & Previously Harvested & -7.63 & .715 \\
\cline { 2 - 4 } & Control I & -19.23 & .001 \\
\cline { 2 - 4 } & Control II & -19.53 & .001 \\
\hline \multirow{3}{*}{ Previously Harvested } & Harvested & 7.63 & .715 \\
\cline { 2 - 4 } & Control I & -11.60 & .112 \\
\cline { 2 - 4 } & Control II & -11.90 & .095 \\
\hline Control I & Harvested & 19.23 & .001 \\
\cline { 2 - 4 } & Previously Harvested & 11.60 & .112 \\
\cline { 2 - 4 } & Control II & -0.30 & 1.000 \\
\hline \multirow{3}{*}{ Control II } & Harvested & 19.53 & .001 \\
\cline { 2 - 4 } & Previously Harvested & 11.90 & .095 \\
\cline { 2 - 4 } & Control I & 0.30 & 1.000 \\
\hline
\end{tabular}

Pearson Chi-square tests for kinnikinnick cover classes reveal a significant relationship between the cover classes of the four sites $(\mathrm{P}<0.05)$. The cover class 
frequency rankings were lower for the harvested site compared to the two controls and the previously harvested sample sites (Table VII).

\section{TABLE VII}

KINNIKINNICK COVER CLASS FREQUENCIES AND CHI-SQUARE TEST (COVER CLASSES BEGIN AT IV FOR THESE SITES)

\begin{tabular}{|c|c|c|c|c|c|}
\hline \multirow[b]{2}{*}{ Cover Classes } & \multicolumn{4}{|c|}{ Plot Type } & \multirow[b]{2}{*}{ Total } \\
\hline & Harvested & $\begin{array}{l}\text { Previously } \\
\text { Harvested }\end{array}$ & Control I & Control II & \\
\hline IV $16-25 \%$ & 6 & 1 & 1 & 0 & 8 \\
\hline V $\quad 26-35 \%$ & 7 & 9 & 5 & 4 & 25 \\
\hline VI $\quad 36-45 \%$ & 8 & 6 & 4 & 3 & 21 \\
\hline VII $46-55 \%$ & 3 & 6 & 4 & 4 & 17 \\
\hline VIII 56-65\% & 3 & 2 & 2 & 6 & 13 \\
\hline IX $\quad 66-75 \%$ & 2 & 4 & 5 & 7 & 18 \\
\hline X $76-85 \%$ & 1 & 1 & 5 & 5 & 12 \\
\hline XI $\quad 86-95 \%$ & 0 & 1 & 3 & 0 & 4 \\
\hline XII $96-100 \%$ & 0 & 0 & 1 & 1 & 2 \\
\hline \multirow{2}{*}{\multicolumn{2}{|c|}{$\begin{array}{l}\text { Test } \\
\text { Pearson Chi-square }\end{array}$}} & $\mathrm{N}$ & $\mathrm{df}$ & Sig. & \\
\hline & & 120 & 27 & .043 & \\
\hline
\end{tabular}

Stem measurements for cut and uncut kinnikinnick were averaged and compared to determine whether the amount of stem removed was compliant with Forest Service specifications. Results demonstrate that the harvest was compliant with regulations, with average stem height cut $(5.57 \mathrm{~cm})$ two centimeters below the suggested cut height for kinnikinnick. 
Yarrow

Mann-Whitney U-test results revealed a significant difference in yarrow cover between the Flag Point harvest and control sites $(\mathrm{U}=816.500 ; \mathrm{P}<0.001)$. The mean cover for the harvested site is significantly lower than the control site (Table VIII; Figure 3). The same test revealed different results for the Denest Spring sites. No significant difference was found between the harvest and control sites $(\mathrm{U}=1368.000 ; \mathrm{P}$ $=.151)$ and the mean cover was higher in the harvested site than the control site (Table VIII).

\section{TABLE VIII}

DESCRIPTIVE STATISTICS AND MANN-WHITNEY U-TEST RESULTS FOR THE FLAG POINT AND DENEST SPRING YARROW SITES

\begin{tabular}{|l|c|c|c|c|c|}
\hline Site & $\begin{array}{c}\text { Quadrats } \\
\mathrm{N}\end{array}$ & $\begin{array}{c}\text { Cover } \\
\text { Mean (\%) }\end{array}$ & SD & $\begin{array}{c}\text { Mann-Whitney U- } \\
\text { Test }\end{array}$ & Sig. \\
\hline Flag Point Harvest & 122 & 3.36 & 3.55 & 816.5 & $<0.001$ \\
Flag Point Control & 30 & 9.58 & 7.67 & & \\
\hline Denest Spring Harvest & 110 & 9.31 & 9.60 & 1368.0 & .151 \\
Denest Spring Control & 30 & 6.08 & 6.25 & & \\
\hline
\end{tabular}

The cover class frequency rankings for the Flag Point harvest site are lower overall than Flag Point control site frequencies (Table IX). The Pearson Chi-square test reveals a significant difference between the cover classes of the harvest and control sites $(\mathrm{P}<0.001)$. A majority of the harvested plots $(85 \%)$, have between $0-5 \%$ yarrow cover while the same proportion of the control plots have between 1-25\% yarrow cover. In contrast to the Flag Point sites, cover classes for the Denest Spring 
harvest and control sites were not significantly different as shown by the Chi-square analysis $(\mathrm{P}=.592$; Table IX). However, the overall cover class frequency rankings for the control site were substantially lower than the harvest sites (Table IX).

TABLE IX

YARROW COVER CLASS FREQUENCIES AND CHI-SQUARE TESTS

\begin{tabular}{|c|c|c|c|c|c|c|}
\hline \multirow{2}{*}{ Cover Classes } & \multicolumn{3}{|c|}{ Flag Point } & \multirow{2}{*}{\multicolumn{3}{|c|}{ Denest Spring }} \\
\hline & Harvest & & Control & & & Control \\
\hline $\begin{array}{ll}1 & 0-1 \% \\
11 & 1-5 \%\end{array}$ & 38 & & 3 & 22 & & 7 \\
\hline II $1-5 \%$ & 66 & & 9 & 29 & & 11 \\
\hline III $6-15 \%$ & 16 & & 11 & 37 & & 10 \\
\hline IV $16-25 \%$ & 2 & & 6 & 17 & & 2 \\
\hline $\begin{array}{ll}V & 26-35 \%\end{array}$ & 0 & & 1 & 2 & & 0 \\
\hline VI $36-45 \%$ & 0 & & 0 & 3 & & 0 \\
\hline $\begin{array}{l}\text { Test } \\
\text { Pearson Chi-Sruar }\end{array}$ & $\mathrm{N}$ & $d f$ & Sig. & $\mathrm{N}$ & df & Sig. \\
\hline Pearson Chi-Square & 152 & 4 & $<0.001$ & 140 & 5 & .592 \\
\hline
\end{tabular}

\section{Oregon Grape}

Mann-Whitney U-test results show a significant difference between the harvested and control site for Oregon grape $(U=35.000 ; \mathrm{P}<0.001)$. The mean cover of Oregon grape in the harvested site is significantly lower than in the control site (Table X; Figure 3). Results indicate a 51\% decrease in Oregon grape post-harvest cover. 
TABLE X

DESCRIPTIVE STATISTICS AND MANN-WHITNEY U-TEST RESULTS FOR THE OREGON GRAPE HARVEST AND CONTROL SITES

\begin{tabular}{|l|c|c|c|c|c|}
\hline Site & $\mathrm{N}$ & $\begin{array}{c}\text { Cover } \\
\text { Mean (\%) }\end{array}$ & SD & $\begin{array}{c}\text { Mann-Whitney U- } \\
\text { Test }\end{array}$ & Sig. \\
\cline { 1 - 4 } Harvest & 73 & 10.11 & 11.85 & 35.000 & $<0.001$ \\
\cline { 1 - 3 } Control & 33 & 71.03 & 19.32 & & \\
\hline
\end{tabular}

The Pearson Chi-square test shows a significant difference between cover class and site-type $(\mathrm{P}<0.001)$. The cover class frequency counts were much higher for the control site than the harvest site (Table XI). None of the harvested plots had over $75 \%$ Oregon grape cover. In contrast, the majority $(86 \%)$ of the control plots had over $75 \%$ Oregon grape cover.

TABLE XI

OREGON GRAPE COVER CLASS FREQUENCIES AND CHI-SQUARE TEST

\begin{tabular}{|ll|c|c|}
\hline \multicolumn{2}{|l|}{ Cover Classes } & Harvest & Control \\
\hline I & $0-1 \%$ & 17 & 0 \\
II & $1-5 \%$ & 24 & 0 \\
III & $6-15 \%$ & 18 & 1 \\
IV & $16-25 \%$ & 5 & 0 \\
V & $26-35 \%$ & 6 & 0 \\
VI & $36-45 \%$ & 2 & 2 \\
VII & $46-55 \%$ & 1 & 4 \\
VIII & $56-65 \%$ & 0 & 6 \\
IX & $66-75 \%$ & 0 & 5 \\
X & $76-85 \%$ & 0 & 9 \\
XI & $86-95 \%$ & 0 & 5 \\
XII & $96-100 \%$ & 0 & 1 \\
& & 0 & \multicolumn{2}{|c|}{} \\
\hline Test & N & df & Sig. \\
Pearson Chi-Square & 106 & 11 & $<0.001$ \\
\hline
\end{tabular}




\section{CHAPTER V}

\section{DISCUSSION}

\section{MEDICINAL PLANT ADMINISTRATION}

"where the resource is a commons, open access to all, the creation or expansion of a market is more likely to accelerate depletion rather than to create an incentive for its conservation" (Crook and Clapp 1998, p. 136)

The increased demand for special forest products and for medicinal plants in particular, highlights the need for consistent harvest regulations and plant monitoring studies. Forest Service restrictions on commercial medicinal plant harvests are rarely implemented and enforced. The moratorium placed on valerian at the Barlow Ranger District, is the only medicinal plant harvest restriction that has been imposed on the Mount Hood National Forest. Forest Service budgetary constraints, limited knowledge of medicinal plant harvests, and the small amounts of revenue generated from the sale of medicinal plant permits, hinder regulation and enforcement of harvest yields.

The extent of illegal medicinal plant harvest on the Mount Hood National Forest is unknown. Illegal harvests of other special forest products such as beargrass and cascara are well publicized and, according to a Bureau of Land Management official, poaching of other understory plants is on the rise (Greimel 1999). An ordinance issued by the State of Oregon to discourage illegal harvests on private and public land (ORS 1641813-2), requires herb buyers to verify harvester permits when purchasing raw 
materials (Richards, pers. comm 1999). Whether this method of self-regulation within the herbal industry has been effective in curtailing illegal harvests is unknown.

Harvesters who do not acquire the appropriate medicinal plant permits, do so for various reasons. Many harvesters who extracted plant materials before the 1993 implementation of permit laws, resent paying for a resource that they used to harvest for free (Adese, pers. comm 1999). The perception that resources on public lands are "common goods" fosters this reluctance to pay permit fees. In addition, harvesters are reluctant to reveal the location of harvest sites because of a perceived risk of losing access to the resource. Fee systems have also become complex, with different prices established for different forest products by state, county, and federal authorities (Greimel 1999). The lack of understanding of the permitting regulations among foreign harvesters has also been cited as a reason for illegal harvests (Hansis 1998).

Limited access to permit offices may also contribute to harvesting without permits. For example, employees of an herbal company harvesting yarrow and valerian near the Badger Creek Wilderness area, had to drive approximately $45 \mathrm{~km}$ beyond the harvest site to obtain a permit. Currently, harvest permits for each administrative district must be obtained in that district, regardless of the harvester's proximity to another issuing office.

Unlike other sectors of the special forest products industry, herbal companies tend to engage exclusively in the production, harvesting, and processing 
of medicinal plants. Herbal companies are able to specialize in this way because they cultivate in addition to wildcrafting. Other special forest product sectors, i.e., mushroom and floral greenery, rely entirely on wild source material. Although the herbal sector is not engaged in harvesting special forest products other than medicinals, the plants harvested for medicinal purposes are also used by other sectors in the industry. For example, Oregon grape foliage is used as a floral green. Medicinal plant wildcrafters harvest only the root and parts of the plant up to the first leaves and discard the remaining leafy parts used in floral arrangements.

\section{MEDICINAL PLANT MONITORING ON MOUNT HOOD NATIONAL}

\section{FOREST}

Few Forest Service field studies address the impacts of medicinal plant harvests. The valerian study conducted in the Barlow district is the only long-term medicinal monitoring study on Mount Hood National Forest. This study however, produced inconclusive results for several reasons including too few sampling units and a failure to re-locate all of the units. For the units that could be located, the cover data showed a decline in valerian cover between 1995 and 1999. These results might be explained by differences in the timing of field sampling; for example, 1999 cover data was collected in late October when valerian goes dormant and lacks a robust floristic structure; the 1995 and 1997 cover data was collected mid to late summer when the valerian is in full bloom. Thus, additional 
plots and re-sampling mid to late summer are needed to determine meaningful changes in valerian cover.

Percent cover estimates in my kinnikinnick, yarrow, and Oregon grape study sites appear to effectively detect post-harvest population changes. All of my sites except the Denest Spring yarrow site show a lower percent cover in the harvested plots than the control plots. These data need to be considered cautiously however, as cover measures are affected by changes in density and vigor (Elzinga et al. 1998), and long-term monitoring at each site is needed to identify any longterm effects of harvesting. Nonetheless, these data can provide resource managers with sufficient information to re-direct harvesters to other areas of the National Forest. These data might aid in predicting how other ecologically similar plant species' might respond to harvest.

Collecting cover data before and after harvest can provide precise measures of harvested plant material. Plant responses to specific harvest yields can be determined and compliance with harvest yield regulations can be assessed. However, sampling before harvest can be difficult because it requires researchers to know the exact location of harvest. Where this type of study is not possible, experimental studies such as the valerian monitoring study are needed to determine plant responses to different harvest levels. 


\section{ECOLOGICAL IMPACTS OF MEDICINAL PLANT HARVESTS}

Cover changes at my sample sites suggest harvesting significantly reduces cover of the target species. At all sites (except for one yarrow site), cover was lower in the harvested than control plots (Figure 3).

At the kinnikinnick site, data for plots harvested in previous years showed higher cover than the 1999 harvested plots, but lower than the controls. This indicates that, although the kinnikinnick population in the previously harvested plots has increased since harvest, populations are still not as high as in the control plots. Other factors that can influence these results are harvesting intensities in previous years and environmental variables that can influence plant growth responses such as climatic variability and herbivory.

Harvest intensity and frequency may also influence population recovery. For example, the Denest Spring yarrow site was not harvested prior to 1999 and was selected for harvest because of the dense population of yarrow (Buresh, pers. comm. 1999). The mean yarrow cover at this site is substantially higher than at the Flag Point harvest site which has been harvested for several years. Although consistent harvesting of yarrow at the Flag Point site may explain the lower yarrow cover, Brounstein (1999) suggests that yarrow can be harvested intensely without compromising the population. Other unknown factors may also account for the low yarrow cover at the Flag Point site.

The significant change in Oregon grape cover post-harvest (Figure 3) is attributed to the method of extraction which involves removing the whole plant. 
Long-term monitoring of this harvest site can provide information about the regeneration of this understory dominant and will be especially important as harvest yields increase to meet market demands (Table I).

The long-term impacts of the kinnikinnick, yarrow, and Oregon grape harvests are difficult to determine from existing data. However, several long-term studies address the influence of species removal on plant community structure and stability (e.g., Allen and Forman 1976; Abdul-Fatih and Bazzaz 1979; Aarsen and Epp 1990; Aksenova et al. 1998). For example, Aksenova et al. (1998) examined the responses of subordinate species to the removal of dominant plants in the alpine tundra. In this study, subordinate species experienced a decline in numbers over the course of thirteen years. They concluded that the detrimental changes in the environment caused by dominant species removal resulted in a decrease of subordinate species. These environmental factors include increased exposure to wind dessication, lower temperatures, decreased soil moisture and lack of protection from herbivores (Aksenova et al. 1998). Although the overall community composition did not change, the authors suggest that this may not hold true in less stressful environments. In a similar study, Gurevitch and Unnasch (1989) also found higher productivity and species diversity in a meadow community following removal of the dominant species.

Another impact to associated species is accidental harvest. Mead (1998) found accidental harvesting of sensitive species, narrow-leaved purple coneflower (Echinacea angustifolia), and pale purple coneflower (Echinacea pallida) was 
common in areas where purple coneflower (Echinacea purpurea) were the target species. The strong resemblance among certain plants can make their identification in the field difficult and has important ramifications when endangered species are involved. Misidentification can also result in the harvest of a species that does not have desirable medicinal compounds. At the kinnikinnick site, harvesters extracted kinnikinnick along with Arctostaphylos x media, a non-medicinal hybrid of kinnikinnick and hairy manzanita (Pojar and MacKinnon 1994). In this case, training of harvesters in plant identification would prevent the harvest of nonmedicinals and/or endangered species.

Trampling during harvest may also affect plant communities. Cole (1995) examined plant responses to human and herbivore trampling and found that trampling creates a characteristic plant community dominated by species whose morphology gives them a certain tolerance to bruising and compression. Thus, herbaceous species such as valerian and yarrow would be more impacted by trampling than woody species such as kinnikinnick and Oregon grape. However, certain herbaceous species such as the Penstemon peckii, a plant endemic to southern Oregon, is resilient to trampling and even thrives with moderate disturbances (Brounstein 1999). Although there were no signs of trampled vegetation at my sample sites, areas of bare ground at the kinnikinnick and yarrow sites were disturbed and the topsoil displaced by the harvesters.

The ecological impacts of harvesting depend on the method of harvest. Medicinal plants that are extracted in whole for the root, root bark, rhizome, or 
shoots, are more likely to be impacted by harvests than plants that have their foliage removed. Few studies exist on plant regeneration in response to harvests and the responses of individual species to different methods of extraction, i.e., subjecting plant populations to different intensities of foliage removal to the extraction of the entire plant. However, the results of similar studies may be instructive. For example, Minore and Weatherly (1996) examined the regeneration of Pacific yew stumps after harvesting for taxol production and found yew regeneration is strongly correlated with remaining stump height and the percentage of bark left on the stump after harvest.

Fuller (1991) notes that the removal of bark, roots and rhizomes can interrupt the transport of photosynthates and nutrients and can weaken plant resistance to pests and diseases. Wildcrafted species extracted for their roots or root bark include black cohosh (Cimicifuga racemosa), blue cohosh (Caulophyllum thalictroides), bloodroot (Sanguinaria canadensis), devil's club (Oplopanax horridum), echinacea (Echinacea angustifolia), nettle (Urtica dioica), lomatium (Lomatium dissectum), poke root (Phytolacca americana), Oregon grape, valerian, and yellow dock (Rumex crispus or obtusifolia). Many of these species such as cohosh, echinacea, lomatium, and Oregon grape, are listed as "at risk" or "to watch" by United Plant Savers (1999) because of significant declines from loss of habitat and over-harvesting. Of the medicinal plants listed as "at risk" or "to watch" by United Plant Savers (1999), five are wildcrafted off the Mount Hood National Forest (Table XII). 


\title{
TABLE XII
}

\begin{abstract}
MEDICINAL PLANTS WILDCRAFTED FROM THE MOUNT HOOD NATIONAL FOREST THAT ARE LISTED BY UNITED PLANT SAVERS (1999) AS “AT RISK" OR "TO WATCH” SPECIES
\end{abstract}

\begin{tabular}{|l|l|}
\hline Plant & Status \\
\hline Arnica (Arnica spp.) & To watch \\
\hline Lobelia (Lobelia spp.) & To watch \\
\hline Lomatium (Lomatium dissectum) & At risk \\
\hline Oregon Grape (Berberis aquifolium) & To watch \\
\hline Pipsissewa (Chimaphila umbellata) & To watch \\
\hline & \\
\hline
\end{tabular}

The harvest of foliage, fruits or flowers, may have ecological consequences for wildlife and pollinators. Schlosser et al. (1992) have identified many bird and mammal species that forage extensively on the berries of commercially harvested floral greens such as salal and huckleberry. The berries of medicinal species such as kinnikinnick and Oregon grape are also consumed by large mammals such as bear (Mathews 1988). Any reductions in these plant populations could adversely affect the wildlife that depend on them as a food source.

Most studies that examine the effects of foliage removal on vegetation are herbivory studies (e.g., Kauffman et al. 1983; Kauffman and Krueger 1984; Fleischner 1994; Austin et al. 1986; Case and Kauffman, 1997). Grazing impacts on vegetation are well known and include reduced vegetation cover, vigor, altered species composition, and species diversity (Kauffman and Krueger 1984; 
Fleischner 1994). Although wildcrafting and grazing impacts differ in intensity, the methods used to measure vegetation response in grazing studies may be relevant to foliage removal and whole plant removal harvesting studies.

\section{THE ROLE OF DISTURBANCE IN MEDICINAL PLANT REGENERATION}

Although disturbance studies for other special forest products such as fungus and huckleberries have been conducted (Hosford et al. 1997; Stark and Baker 1992), similar studies involving medicinals are not available. Disturbance plays an important role in creating habitat for many medicinal plants. Early seral conditions created by forest disturbance following fire, timber harvesting, or blowdown create favorable conditions for many herbaceous perennial species. The yarrow sites used in this study are located in 16 year old clearcuts that were underburned following cutting. The ability of yarrow to successfully colonize these types of clearings suggests a certain dependence on forest disturbances to create large canopy gaps. The valerian sites were also in clearcuts. Both yarrow and valerian tend to colonize meadows and open subalpine forest under natural disturbance conditions (Pojar and MacKinnon). Stand replacement in the clearcuts could result in smaller valerian populations as the forest canopy closes.

Kinnikinnick also occupies disturbed sites such as xeric lahar deposits (Franklin and Dyrness 1988). The kinnikinnick sample sites used in this study were located in the lodgepole pine/kinnikinnick climax community type that can dominate areas that have been subjected to volcanic activity (Franklin and Dyrness 
1988). These kinnikinnick sites would not be located in the Old Maid Flats area without the favorable conditions created by the lahar deposits and mudflows. The lodgepole pine/kinnikinnick community type is often considered a stable "climax" but may be successional to Douglas-fir or western hemlock communities (Franklin and Dyrness 1988).

In western Oregon, Oregon grape is an understory dominant in late seral//"climax" western hemlock forests (Franklin and Dyrness 1988). Oregon grape is sensitive to changes in moisture regimes and generally does not survive disturbances that create early secondary successional conditions, such as clearcuts or wildfires (Brounstein 1999). However, following forest canopy reestablishment, Oregon grape will usually recolonize these sites. Although forest seral stages can be correlated with the abundance of understory plants, little is known about the capability of ecosystems to support harvests. The effects of medicinal plant harvests on succession can only be determined using data from long-term monitoring studies.

\section{SUSTAINABLE HARVESTING GUIDELINES AND POLICY}

Sustainable extraction methods mitigate potential harvesting impacts. Sustainable wildcrafting is defined as the removal of individuals from a population that is conducted at a rate and in a manner that can be continued indefinitely (Freese 1998). Low impact harvesting guidelines have been established by herbalists, the Forest Service, and herbal companies that rely on wildcrafted 
resources. Many of the guidelines tend to be general and reflect little knowledge of the biological characteristics and ecological functions of many medicinal plant species. One notable publication in this area includes harvest methods and specific extraction times for fifty different medicinal plants (Thie 1989). Issues such as the time of day to extract, positive plant identification in the field, avoiding harvest in areas where sensitive plants grow, and only harvesting in areas that have more than $30 \%$ cover of the desired medicinal species, are guidelines suggested by herbalists to reduce harvest impacts.

Districts on the Mount Hood National Forest lack well developed harvest guidelines and species-specific harvesting recommendations. Those guidelines currently in place are less restrictive than those established by herbalists and allow $50 \%$ harvest of a given species in an area versus $30 \%$ recommended by herbalists.

Indirect impacts of wildcrafting include the substitution of more common medicinal plants for those that are in high demand but whose supply cannot meet that demand. For example, Oregon grape is used to substitute for goldenseal, one of the "world's best selling herbs" (Mead 1998). Goldenseal is marketed as a cleanser for the liver, blood and kidneys and to mask the presence of illegal drugs in urine, and has become a popular remedy which has contributed to its growing scarcity in the wild (Fuller 1991). Oregon grape, which has similar constituents to goldenseal (berberine and hydrastine), is being harvested to compensate for this supply shortage (Brounstein 1999). Dwindling wild supplies of herbs in other countries can also result in increased demands for similar species in the United 
States. The demand for wild Panax quinquefolia (American ginseng), harvested from forests of the eastern United States, has increased as supplies of Asian ginseng decrease. Harvesters can earn $\$ 200$ to $\$ 300$ a pound for the wild American ginseng which has resulted in the over-harvest of the species and its listing as an endangered species by United Plant Savers (Vance 1995).

\section{RECOMMENDATIONS}

To ensure the sustainability of medicinal plant harvests, a number of administrative and industry issues should be addressed. Foremost among these is the need for additional scientific research to assist in making informed management decisions. Specifically, little is known about individual taxa and their responses to harvest so that sustainable levels of harvest can be determined. A possible model for this type of research is the systematic study of selective plant thinning over several growing seasons currently being proposed by the Eastern Native Plant Alliance. The objective of their study is to determine sustainable levels of harvest controlling for variables such as microclimate, soil, nutrients, substrate and genotype (Fuller 1991).

Becoming more familiar with plant species morphologies, distributions, and responses to harvest will require extensive research by botanists, biogeographers, plant ecologists, herbalists, and forest managers. In addition, more research on the medicinal compounds of wildcrafted herbs is needed. Research by Cech (1999) on goldenseal revealed that the alkaloids berberine and hydrastine, are present not only 
in the root and rhizome but also in the leaves and stems. Historically, goldenseal harvest has involved the extraction of the whole plant and findings such as this may promote the harvest of renewable plant parts.

Special Forest Product Coordinators at some of the districts on the Mount Hood National Forest were not able to make harvest data available because of database changes in 1998. These types of records should be accessible to other district personnel or researchers in order to track changes in demand for specific species, monitor the types of species harvested, and assess the conditions of these harvest areas. These records in conjunction with photo plot records could then be used to inform managers where and when to re-direct harvesters to other areas, or impose moratoriums. These recommended areas of harvest should also be monitored so that changes in the plant communities can be detected. Modifications of existing methodological approaches used to monitor recreational impacts of natural areas, such as Cole's (1986) study on campsites in the Eagle Cap Wilderness, Oregon, should also be considered for monitoring harvest-induced changes to plant communities. Monitoring protocol and management guidelines for commercial mushroom harvests as set forth by Molina et al. (1993) should also be consulted to guide medicinal plant management.

Longevity is a key component to a monitoring study. Research projects need to survive personnel turnovers and budget uncertainties. Collaboration between the Forest Service and other agencies, institutions, or businesses may be one option to share the responsibility of supervising and monitoring research 
projects. This would provide additional sources of funding and reduce the likelihood of the project being abandoned as a result of personnel changes.

Herbalists who have been involved in the industry for years are knowledgeable about the species they harvest, how the herbs regenerate, and how the population distributions change in response to harvest. Some herbalists have made much of their knowledge about specific plants and their habitats accessible (Brounstein 1999), and are a resource that should be further consulted in order to develop effective, sustainable guidelines for medicinal plant harvests. Mycological societies already play an active role in publicizing commercial mushroom harvests including advocating legislative restrictions on commercial harvests on Oregon state lands (McLain et al. 1998). Recreational herbalists and others involved in the medicinal plant industry need to collaborate more closely to educate the public about the harvest of medicinal plants, and address ways to self-regulate the industry to encourage sustainable harvest methods and discourage illegal harvests.

Much of the literature regarding medicinal plant harvests refers to the need to increase domestic cultivation of medicinal herbs (Mead 1998; Masood 1997; Phillipson 1997; Foster 1993; Fuller 1991). Although this does not prevent continued harvests of wild populations, it provides an alternative to wildcrafting and is an effective way to ensure supplies of specific herbs.

The two most important issues surrounding medicinal plant harvests on the Mount Hood National Forest are thus apparent. First, there is an increasing need for more effective administration and enforcement of medicinal plant harvests. 
Second, budgetary and political realities suggest that educating wildcrafters and providing incentives to harvesters to help develop and subscribe to sustainable methods of harvest, is the most expedient method of reducing the potential impacts of medicinal plant harvesting. 


\section{CONCLUSION}

This study contributes to a small but growing literature that addresses medicinal plant harvests by identifying wildcrafted medicinal plant species and the impacts of harvest on target species cover. With many plant species currently at risk of extinction as a result of habitat loss, the introduction of non-native species, and over-harvest, these types of plant removal studies are especially relevant. In light of increased demands for wildcrafted species, additional research on species responses to harvest and the impacts on plant community structure and function is needed to develop a sustainable industry and prevent biodiversity loss.

An ecosystem-based approach to management that considers the commercial and non-commercial values of medicinal plant species should be considered by the Forest Service to ensure the sustainability of these resources. Priority should be placed on monitoring harvest areas and developing species and community-specific management directives. For example, management directives for yarrow, an early successional species, must consider the importance of natural and human-induced disturbances such as wind-throw and fire to create canopy gaps whereas Oregon grape is dependent on shade provided by late successional stands.

With increased competition for access to these resources on public lands, managing agencies will need to re-consider current enforcement procedures and harvesting guidelines. In addition, the herbal industry needs to be self-regulated to encourage 
sustainable harvesting methods and legal harvests of these public resources. Increased collaboration between land management agencies, harvesters/producers, recreational herbalists, other special forest product industries, and researchers is necessary to establish directives for the sustainable development of this growing industry.

The Forest Service has been creating partnerships with the private sector to help create special forest product inventories and compile informational databases (Borsting 1998). These efforts are in response to increased demands for special forest products and should be accompanied by administrative guidelines consistent across districts within the Mount Hood National Forest. This includes coordinating the permitting process across districts and adopting the most conservative methods of harvest (e.g., $30 \%$ harvest versus $50 \%$ ) to ensure sustainability.

The Forest Service, in conjunction with local medicinal plant industries, should consider training courses for harvesters that include information about harvest areas, methods of harvest that are species-specific, techniques to be employed during harvest to promote plant regeneration (especially with wholeplant harvests), and appropriate harvest times. To encourage participation, the Forest Service could provide permitting incentives to harvesters and companies. Benefits would include improved Forest Service/harvester relationships and harvester notification of areas where the understory could be harvested prior to timber cutting operations or controlled burns. 
Because restrictions of these botanical resources by the Forest Service could promote increased illegal harvests, the Forest Service should consider forming partnerships with herbal companies, individual harvesters, interested scientists, and members of the public. This strategy might include long-term lease options for harvesters that provide some privileges but do not make these areas inaccessible to other users or harvesters. Other incentives might be provided to make permitees stewards of the areas in which they wildcraft.

Collaboration with other national forests would also aid in the development of the special forest products programs. Currently, the Deschutes, Winema, Umpqua, and Willamette National Forests issue special forest product permits that are valid in all those Forests (Luoma 1999). Because of budgetary restrictions, many of the Special Forest Product Coordinators at the Mount Hood National Forest are only able to spend a minimal amount of their work week administering the special forest products program (Anonymous, pers. comm. 1999). With increased recognition of the economic viability in special forest products, Forest Service personnel may be more willing to allocate more staff time to administer the program.

Partnerships between the medicinal plant companies and other special forest product industries could also increase the effective use of all the harvested plant materials and reduce the overall impacts of harvest by the special forest products industry. This collaboration could also reveal additional products that serve multiple industry uses. 
This study examined the legal collection of wild medicinal plant species from the Mount Hood National Forest. My results show that eleven medicinal plant species are commonly collected from the Mount Hood National Forest by two local herbal companies for the commercial herb market. Both companies generally harvest in areas recommended by the U.S. Forest Service, and tend to return to the same harvest locations from season to season. Markets for the locally harvested herbs are domestic, with most of these products being sold in natural food stores. The medicinal plant species examined in this study have wide distributions and are abundant on the National Forest, however, it is important to understand how each species responds to harvest to determine the sustainability of this harvest industry.

Results from my field study suggest that harvesting significantly impacts the cover of the target medicinal species. In all cases except for one yarrow site, cover was significantly lower in the harvested plots than in the control plots. However, because the cover measures for the harvested plots were generally recorded immediately after harvest, my measures can not take into account regeneration of the plants or plant parts. For this reason, it is important that permanent sample plots be established to monitor the long-term effects of harvest on the target populations and their associated species. Results from long-term studies are needed to establish appropriate guidelines and regulations for the commercial harvest of these species. 


\section{REFERENCES}

Aarssen, L.W. and Epp, G.A. 1990. Neighbor Manipulations in Natural Vegetation: A Review. Journal of Vegetation Science 1: 13-30.

Abdul-Fatih, H.A. and Bazzaz, F.A. 1979. The Biology of Ambrosia trifida L.I. Influence of Species Removal on the Organization of the Plant Community. New Phytologist 83: 813-816.

Adesse, Allan. 1999. Personal Communication (May 14, 1999). Wildcrafter, Grants Pass, Oregon.

Aksenova, A.A., Onipchenko, V.G., and Blinnikov, M.S. 1998. Plant Interactions in Alpine Tundra: 13 Years of Experimental Removal of Dominant Species. Ecoscience 5: 258-270.

Allen, E.B. and Forman, F.A. 1976. Plant Species Removals and Old-field Community Structure and Stability. Ecology 57: 1233-1243.

Austin, D.D., Urness, P.J., and Riggs, R.A. 1986. Vegetal Change in the Absence of Livestock Grazing, Mountain Brush Zone, Utah. Journal of Range Management 39: 514-517.

Blatner, K.A. 1997. Special Forest Product Markets in the Pacific Northwest with Global Implications. In: Special Forest Products: Biodiversity Meets the Marketplace (GTR-WO-63). Corvallis: USDA Forest Service, Pacific Northwest Research Station.

Borsting, M. 1998. Subcommittee on Forests and Public Land Management, Oversight Hearing on Specialty Forest Products. February 25, 1998: Washington, D.C.

Brevoort, P. 1998. The Booming U.S. Botancial Market: A New Overview. Herbalgram 44: 33-46.

Brounstein, H. 1999. http://metalab.unc.edu/herbmed/neat-stuff/hydrasti.html. 8/20/99.

Buresh, Randall. 1999. Personal Communication (August 16, 1999). Owner, Oregon's Wild Harvest, Sandy, Oregon. 
Burt, J.E. and Barber, G.M. 1996. Elementary Statistics for Geographers. New York: The Guilford Press.

Cameron, K.A. and Pringle, P.T. 1986. Post-Glacial Lahars of the Sandy River Basin, Mount Hood, Oregon. Northwest Science 60: 225-237.

Cameron, K.A. and Pringle, P.T. 1987. A Detailed Chronology of the Most Recent Major Eruptive Period at Mount Hood, Oregon. Geological Society of America Bulletin 99: 845-851.

Case, R.L. and Kauffman, J.B. 1997. Wild Ungulate Influences on the Recovery of Willows, Black Cottonwood and Thin-leaf Alder Following Cessation of Cattle Grazing in Northeastern Oregon. Northwest Science 71: 115-126.

Cech, R. 1999. Balancing Conservation with Utilization: Restoring Populations of Commercially Valuable Medicinal Herbs in Forests and Agroforests. United Plant

Savers Newsletter, May 1999.

Craig, L. 1998. Hearing before the Subcommittee on Forests and Public Land Management. The Committee on Energy and Natural Resources, United States Senate- 105th Congress. February 25, 1998: U.S. Government Printing Office, Washington, D.C.

Cole, D.N. 1986. Ecological Changes on Campsites in the Eagle Cap Wilderness, 1979-1984 (Research Paper INT-368). USDA Forest Service, Intermountain Research Station.

Cole, D.N. 1995. Experimental Trampling of Vegetation: Predictors of Resistance and Resilience. Journal of Applied Ecology 32: 215-224.

Crook, C. and Clapp, R.A. 1998. Is Market-Oriented Forest Conservation a Contradiction in Terms? Environmental Conservation 25: 131-145.

Elzinga, C.L., Salzer, D.W., and Willoughby, J.W. 1998. Measuring and Monitoring Plant Populations (BLM-RS-ST-98-005-1730). Denver: USDI Bureau of Land Managment, National Applied Sciences Resources Center.

Fleischner, T.L. 1994. Ecological Costs of Livestock Grazing in Western North America. Conservation Biology 8: 629-644.

Foster, S. 1990. Notes on the Undeveloped Potential of Medicinal Plants for the Southern Appalachians; A Discussion Paper. Paper submitted March 1990 to the SAMAB/Forest Service Workshop on Botanicals and Pharmaceuticals. 
Foster, S. 1993. Medicinal Plant Conservation and Genetic Resources: Examples from the Temperate Northern Hemisphere. Acta Horticulturae 330: 67-74.

Foster, S. 1995. Forest Pharmacy: Medicinal Plants in American Forests. Durham, N.C.: Forest History Society.

Franklin, J.F. and Dyrness, C.T. 1988. Natural Vegetation of Oregon and Washington. Corvallis: OSU Press.

Freed, J. 1995. Special Forest Products: Past, Present, Future. International Journal of Ecoforestry 11: 62-67.

Freese, C. H. 1998. Wild Species as Commodities: Managing Markets and Ecosystems for Sustainability. Washington, D.C.: Island Press.

Fuller, D.O. 1991. Medicine from the Wild: An Overview of the U.S. Native Medicinal Plant Trade and its Conservation Implications. Washington, D.C.: World Wildlife Fund.

Greimel, H. 1999. Forest Poachers Raid Undergrowth Treasure. The Oregonian. September 5: D1, D7.

Gurevitch, J. and Unnasch, R.S. 1989. Experimental Removal of a Dominant Species at Two Levels of Soil Fertility. Canadian Journal of Botany 67: 3470-3477.

Halverson, N.M., Lesher, R.D., and McClure, R.H. Jr. 1986. Major Indicator Shrubs and Herbs on National Forests of Western Oregon and Southwestern Washington (R6-TM-229-1986). Portland: USDA Forest Service, Pacific Northwest Region.

Hansis, R. 1998. A Political Ecology of Picking: Non-timber Forest Products in the Pacific Northwest. Human Ecology 26: 67-86.

Hosford, D., Pilz, D., Molina, R., and Amaranthus, M. 1997. Ecology and Management of the Commercially Harvested American Matsutake Mushroom (PNW-GTR-412). Portland: USDA Forest Service, Pacific Northwest Research Station.

Howes, S. 1979. Soil Resource Inventory. USDA Forest Service, Pacific Northwest Region, Mount Hood National Forest. U.S. Government Printing Office: Washington, D.C. 
Jones, Steven. 1999. Personal Communication (July 6, 1999). Special Forest Products Coordinator, Hood River Ranger District, Hood River, Oregon.

Joyce, C. 1990. Cancer Drug Found in Bark of American Tree. New Scientist 128: 20.

Kantor, S. 1994. Local Knowledge and Policy Development: Special Forest Products in Coastal Washington. Master's thesis, University of Washington, Seattle.

Kauffman, J.B., Krueger, W.C., and Vavra, M. 1983. Effects of Late Season Cattle Grazing on Riparian Plant Communities. Journal of Range Managment 36: 685-690.

Kauffman, J.B. and Krueger, W.C. 1984. Livestock Impacts on Riparian Ecosystems and Streamside Management Implications: A Review. Journal of Range Management 37: 430-438.

Lampietti, J.A. and Dixon, J.A. 1995. To see the Forest for the Trees: A Guide to Non-Timber Forest Benefits (Environment Department Paper 013).

Washington, D.C.: The World Bank.

Luoma, D.L. 1999. Mushrooms and Timber: Managing Commercial Harvesting in the Oregon Cascades. Journal of Forestry 97: 4-11.

Lyke, J. and Brooks, D.J. 1995. World Supply and Demand for Forest Products. Journal of Forestry 93: 22-26.

Marwick, C. 1995. Growing Use of Medicinal Botanicals Forces Assessment by Drug Regulators. Journal of the American Medical Association 273: 607609.

Masood, E. 1997. Medicinal Plants Threatened by Over-use. Nature 385: 570.

Mathews, D. 1988. Cascade-Olympic Natural History. Portland: Raven Editions.

McChesney, J. 1996. Biological Diversity, Chemical Diversity and the Search for New Pharmaceuticals. In Medicinal Resources of the Tropical Forest: Biodiversity and its Importance to Human Health, eds. M. Balick, E. Elisabetsky and S. Laird, pp.11-18. New York: Columbia University Press.

McLain, R.J., Christensen, H.H., and Shannon, M.A. 1998. When Amateurs are the Experts: Amateur Mycologists and Wild Mushroom Politics in the Pacific Northwest, USA. Society and Natural Resources 11: 615-626. 
Mead, N. 1998. The Endangered Herbs: The Rocketing Popularity of Natural Remedies is Threatening Ginseng, Goldenseal and Other Plants. Utne Reader Jul/Aug 88: 10-12.

Minore, D. and Weatherly, H.G. 1996. Stump Sprouting of Pacific Yew (PNWGTR-376). Portland: USDA Forest Service, Pacific Northwest Research Station.

Molina, R., O’Dell, T., Louma, D., Amaranthus, M., Castellano, M., and Russel, K. 1993. Biology, Ecology, and Social Aspects of Wild Edible Mushrooms in the Forests of the Pacific Northwest: A Preface to Managing Commercial Harvest (PNW-GTR-309). Portland: USDA Forest Service, Pacific Northwest Research Station.

National Weather Service, National Oceanic and Atmospheric Administration. 1999. http://www.wrcc.dri.edu/cgi-bin/clirectm.pl?oresta. 5/02/00.

Newport News Times. 1999.

http://www.newportnewstimes.com/news/nt_news0326.13.4/19/99.

Newton, I. 1957. The Gathering Industry West of the Cascades. Master's Thesis, Oregon State University, Corvallis.

Orr, E.L., Orr, W.N., and Baldwin, E.M. 1992. Geology of Oregon. Dubuque: Kendall/Hunt Publishing Company.

Peck, M.E. 1961. A Manual of the Higher Plants of Oregon. Portland: Binfords and Mort Publishing Company.

Peters, C.M. 1996. The Ecology and Management of Non-Timber Forest Resources (World Bank Technical Paper ISSN 0253-7494-322). Washington, D.C.: The World Bank.

Phillipson, D.J. 1997. Biology in Action: Medicinal Plants. Journal of Biological Education 31: 109-115.

Pierce, A.R. 1999. The Challenges of Certifying Non-timber Forest Products. Journal of Forestry 97: 34-37.

Pojar, J. and MacKinnon A. 1994. Plants of the Pacific Northwest Coast:

Washington, Oregon, British Columbia and Alaska. Redmond, Washington:

Lone Pine Publishing. 
Richards, R.T. 1997. What the Natives Know: Wild Mushrooms and Forest Health. Journal of Forestry 95: 5-10.

Richards, Sue. 1999. Personal Communication (October 14, 1998). Special Forest Products Coordinator, Clackamas-Estacada Ranger District, Mount Hood National Forest, Oregon.

Robbins, C.S. 1998. Medicinal Plant Conservation- A Priority at Traffic. Herbalgram 44: 52-54.

Robinson, C. 1994. Multiple Perspectives: Rules Governing Special Forest Products Managment in Coastal Washington. Master's Thesis, University of Washington, Seattle.

Savage, M. 1995. Pacific Northwest Special Forest Products: An Industry in Transition. Journal of Forestry 93: 6-11.

United Plant Savers. 1999. Savers At Risk Forum.

http://www.plantsavers.org/Newsletter/id.html. 5/14/99.

Schlosser, W.E., Blatner, K.A., and Chapman, R. 1991. Economic and Marketing Implications of Special Forest Products Harvest in the Coastal Pacific Northwest. Pullman, Washington: Washington State University, Department of Natural Resource Sciences.

Schlosser, W.E., Blatner, K.A., and Zamora, B. 1992. Pacific Northwest Forest Lands Potential for Floral Greenery Production. Northwest Science 66: 4455.

Schlosser, W.E. and Blatner, K.A. 1995. The Wild Edible Mushroom Industry of Washington, Oregon and Idaho: A 1992 Survey of Processors. Journal of Forestry 93: 31-36.

Schlosser, W.E. and Blatner, K.A. 1997. Special Forest Products: An East-side Perspective (PNW-GTR 380). Portland: USDA Forest Service, Pacific Northwest Research Station.

Sears, C. 1995. The easy way to sell drugs. New Scientist 148: 36-40.

Sonnabend, Cheryl. 1999. Personal Communication (March 24, 2000). Special Forest Service Coordinator, Barlow Ranger District, Dufur, Oregon. 
Stark, N. and Baker, S. 1992. The Ecology and Culture of Montana Huckleberries: A Guide for Growers and Researchers. Missoula, Montana: Montana Forest and Conservation Experiment Station, School of Forestry, The University of Montana.

Thie, K. 1989. A Plant Lovers Guide to Wildcrafting: How to Protect Wild Places and Harvest Medicinal Herbs. White Salmon, Washington: Longetivity Herb Press.

Tilford, G.L. 1997. Edible and Medicinal Plants of the West. Missoula, Montana: Mountain Press Publishing Company.

Vance, N.C. 1995. Medicinal Plants Rediscovered. Journal of Forestry 93: 8-9.

Veblen, T.T. 1989. Biogeography. In Geography in America, eds. C.J. Willmott and G.L. Gaile. Columbus, Ohio: Merrill Publishing Company.

von Hagen, B. and Fight, R.D. 1999. Opportunities for Conservation-Based Development of Nontimber Forest Products in the Pacific Northwest (PNWGTR-473). Portland: USDA Forest Service, Pacific Northwest Research Station. 
APPENDIX A. Interview Questions for Forest Service Special Forest Products Coordinators

1) Could you describe the permitting process with respect to special forest products?

2) Is there permit data available for medicinal plants? If so, can you tell me how many permits were issued in 1999 and for which species? Do the permit applications ask for the harvest locations or do you suggested particular harvest sites?

3) Is there permit data available for other special forest products such as floral greens, Christmas ornamentals or edible mushrooms? If so, how many permits were issued? Are certain harvest sites for these species recommended by the Forest Service?

4) Who is responsible for the management/administration of special forest products at the district level?

5) Are you familiar with the extent to which medicinal plants are harvested commercially on the Mount Hood National Forest? If yes: do you know how many harvesters are involved in the extraction? Do you know if the numbers involved in harvesting have changed over time?

6) Do your back-country or front-country reports include any information on harvesting? How many contacts have been made between Forest Service personnel and harvesters? Have disturbed areas been noted in reports?

7) Are photo plots available for areas of the Mt. Hood National Forest? Can they be accessed to determine any changes in under-story composition or frequency?

8) With regard to trail counter numbers, are some areas seeing large increases in visitors where certain plants might be located?

9) What guidelines do the Forest Service provide for the harvest of medicinal plants? 
10) Are any management plans being considered with respect to the harvest of special forest products on the Mount Hood National Forest?

11) Has the Forest Service been involved in any type of public education or used other preventative measures aimed at reducing illegal commercial harvests? 
APPENDIX B. Interview Questions for Herbal Producers and Harvesters

1) How long have you been operating your harvesting business in Oregon?

2) How many people are involved in the cultivation, processing and packaging of herbs?

3) What herbs do you process here?

4) What species do you domestically cultivate? What percentage of all herbs processed here are domestically cultivated?

5) What percentage of herbs processed here are wildcrafted? What species do you wildcraft and where do you get them? Do you buy herbs from brokers?

6) What are the medicinal uses for the herbs that you wildcraft?

7) Are the markets for your herbs mostly local? Do you export to other areas in the U.S. or overseas?

8) What wildcrafted herbs command the highest prices or are in high demand?

9) Do you cultivate, process or harvest any other types of special forest products?

10) When are your harvesting seasons?

11) Do you have harvest lease agreements with the Forest Service? Do you obtain permits to harvest wild herbs? How much do they cost? Do these costs vary per product?

12) Has the Forest Service provided you with guidelines for commercial harvesting?

13) How many people are engaged in wildcrafting? Are they part-time or full-time employees? What percentage are part-time? Full-time? Do you contract harvesters?

14) Where are your harvest locations? Do you return to the same sites every year? 
15) For each species you wildcraft, what part(s) of the plant do you harvest?

16) For the wildcrafted medicinals, how much of each species did you harvest this year off the Mount Hood National Forest?

17) What tools/instruments do you use to harvest?

18) Do the different species you harvest (if applicable) occur in similar locations to each other? Do they occur in open areas or forested areas? What associated and dominant species occur with the harvested herbs? (overstory and understory)

19) Are you familiar with any other companies or contract harvesters that wildcraft in this area? 